\title{
CARACTERÍSTICAS DO SISTEMA RADICULAR DE POVOAMENTOS DE EUCALIPTOS PROPAGADOS POR SEMENTES E ESTACAS
}

\author{
SERGIO LUIS DE MIRANDA MELLO \\ Engenheiro Florestal
}

Orientador: Prof. Dr. JOSÉ LEONARDO DE MORAES GONÇALVES

\begin{abstract}
Dissertação apresentada à Escola Superior de Agricultura "Luiz de Queiroz", Universidade de Săo Paulo, para obtenção do título de Mestre em Ciências Área de Concentração: Ciências Florestais.
\end{abstract}

\author{
$P$ IR A C I C A B A \\ Estado de São Paulo - Brasil \\ Julho- 1997
}




\section{Dados Internacionais de Catalogação na Publicação (CIP) DIVISÃo DE BIBLIOTECA E DOCUMENTAÇÃO - Campus "Luiz de Queiroz"/USP}

Mello, Sergio Luis de Miranda

Características do sistema radicular de povoamentos de eucaliptos propagados por sementes e estacas / Sergio Luis de Miranda Mello. - - Piracicaba, 1997.

79 p. : il.

Dissertação (mestrado) - - Escola Superior de Agricultura Luiz de Queiroz, 1997. Bibliografia.

1. Clone 2. Eucalipto 3. Raíz I. Título 


\section{CARACTERÍSTICAS DO SISTEMA RADICULAR DE POVOAMENTOS DE EUCALIPTOS PROPAGADOS POR SEMENTES E ESTACAS}

SERGIO LUIS DE MIRANDA MELLO

Aprovado em : 04.09.1997

Comissão julgadora:

Prof. Dr. José Leonardo de Moraes Gonçalves

ESALQ / USP

Prof $^{a}$. Dr ${ }^{a}$ Maria das Graças Ferreira Reis

UFV

Pesq. Dr. Sílvio Crestana

EMBRAPA/CNPDIA

Prof. Dr. Iraê Amaral Guerrini

FCA / UNESP

Prof. Dr. Gerd Sparovek

ESALQ/USP

Prof. Dr. JOSELLEONARDO DE MORAES/GONÇALVES 
Aos meus pais João e Carmela

como uma confirmação do afeto e respeito que tenho por eles.

A todos que contribuiram

na minha formação profissional. 


\section{AGRADECIMENTOS}

À Deus, por mais essa realização na minha vida.

À Escola Superior de Agricultura "Luiz de Queiroz, em particular ao Departamento de Ciências Florestais, pela oportunidade que me foi dada para o aprimoramento de meus conhecimentos e agradável permanência em suas dependências.

Ao Conselho Nacional de Desenvolvimento Científico e Técnológico (CNPq), pelo auxílio financeiro concedido através de bolsa de estudo.

À Fundação de Amparo a Pesquisa do Estado de São Paulo (FAPESP), pelo disponibilização de recursos para a aquisição dos equipamentos (sondas) e reagentes de laboratório.

Ao Programa Temático de Cultivo Mínimo (PTCM) - IPEF, pelo apoio logístico durante a execução dos trabalhos de campo.

Ao Prof. Dr. José Leonardo de Moraes Gonçalves pela competente orientação durante as fases do trabalho.

Ao Luis Eugênio Gonçalves de Oliveira (Tédio), estagiário e aluno de graduação em Engenharia Florestal, pela valiosa colaboração na execução das atividades e pelas ótimas sugestões apresentadas. 
À bióloga e mestranda Marial Izabel Pires Serrano e aos estudantes Sérgio Ricardo (Areião), Kátia (Ipê), Bruno (Mamador), Daniela (Cocão) pelo convívio e colaboração desde o início desta empreitada.

À Cia. CHAMPION PAPEL E CELULOSE Ltda e à Cia. SUZANO DE PAPEL E CELULOSE, que gentilmente cederam 0 uso de suas áreas florestais e não mediram esforços para a viabilização dos trabalhos.

Ao Centro Nacional de Pesquisa, Desenvolvimento e Instrumentação Agrícola (CNPDIA)/EMBRAPA - São Carlos - SP, que através do Pesq. Dr. Sílvio Crestana, prontamente cedeu o acesso e uso do Laboratório de Imagens

Ao Pesquisador Lúcio André de Castro Jorge (EMBRAPA/CNPDIA), pela atenção dada na instrução de uso do programa SIARCS (Sistema Integrado para Análise de Raízes e Cobertura do Solo).

Aos Engenheiros do IPEF: Edward, Cláudio, Roberto e Vanderlei, pelo eficiente apoio logístico e sugestões apresentadas.

À Química Alba Valéria Mosetto, à Técnica em Química Márcia P. Moreno, aos estágiários Fernanda e Marcos (estudantes de técnico em química), pela orientação e execução das análises laboratoriais de solo e planta.

À Prof ${ }^{a} \mathrm{Dr}^{\mathrm{a}}$ Maria das Graças Ferreira Reis da Universidade Federal de Viçosa (UFV), ao Pesquisador Dr. Silvio Crestana da EMBRAPA/CNPDIA - São Carlos e o Prof. Dr. José Leonardo de Moraes Gonçalves, participantes da banca examinadora, pelas valiosas críticas e sugestões.

Para encerrar, agradeço à todas as pessoas e instituiçöes, que direta ou indiretamente colaboraram na realização deste trabalho. 


\section{SUMÁRIO}

Página

RESUMO.

viii

SUMMARY $\mathbf{x i}$

1. INTRODUÇÃO

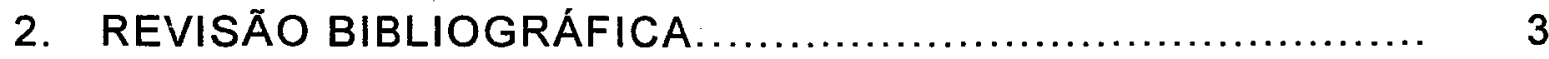

2.1. Classificação das raízes finas............................... 3

2.2. Biomassa de raízes finas.................................... 4

2.3. Distribuição das raízes finas................................ 6

2.4. Fatores que afetam o crescimento de raízes finas.......... 10

2.5. Raízes finas e absorção de nutrientes....................... 12

2.6. Taxa de renovação de raízes finas........................... 13

2.7. Raízes finas e a mineralização de nutrientes................ 16

2.8. Raízes e seus efeitos sobre o solo.......................... 18

2.9. Amostragem de raízes finas................................ 19

2.10. Separação de raízes finas................................ 22

2.11. Avaliação dos principais parâmetros radiculares.......... 22

3. MATERIAL E MÉTODOS..................................... 25

3.1. Caracterização das áreas experimentais.................... 25

3.2. Estudos sobre o sistema radicular....................... 32 
4. RESULTADOS E DISCUSSÃO .............................. 41

4.1. Índices de crescimento e biomassa de diversos compartimentos florestais

4.2. Composição química e estoque de nutrientes

em diversos compartimentos florestais

4.3. Configuração do sistema radicular de árvores

propagadas por sementes e estacas

4.4. Comparação entre métodos de amostragem de

raízes finas

5. CONCLUSÕES

6. REFERÊNCIAS BIBLIOGRÁFICAS 


\title{
CARACTERÍSTICAS DO SISTEMA RADICULAR DE POVOAMENTOS DE EUCALIPTOS PROPAGADOS POR SEMENTES E ESTACAS
}

\author{
Autor: SERGIO LUIS DE MIRANDA MELLO \\ Orientador: Prof Dr. JOSÉ LEONARDO DE MORAES GONÇALVES
}

\section{RESUMO}

O presente estudo teve como objetivos: (i) comparar a amostragem de raízes finas com sondas de 4 e $8 \mathrm{~cm}$ de diâmetro (Área 1); (ii) comparar a amostragem de raízes com sondas e o método do monolito (Área 2) e (iii) caracterizar a distribuição das raizes finas no perfil de solo, no verão e inverno, de materiais genéticos (Eucalyptus grandis (Coff's Harbour) e do híbrido $E$. grandis vs. E. urophylla) propagados por sementes e enraizamento de estacas (Área 2).

Os estudos foram conduzidos no período de 1994 a 1996 em duas áreas experimentais. A Área 1 compreende um plantio comercial de Eucalyptus grandis (Coff's Harbour) com 7 anos de idade, pertencente à Cia. SUZANO PAPEL E CELULOSE, municipio de Itatinga (SP). A Área 2 está localizada num plantio comercial de eucaliptos aos 4,5 anos de idade, propriedade da CHAMPION PAPEL E CELULOSE Ltda., município de Aguaí (SP). O clima das 2 regiões é do tipo Cwa, segundo a classificação de KÖEPPEN. O tipo de solo ocorrente nas 2 áreas é caracterizado como um latossolo vermelho-amarelo, textura média, distrófico, relevo plano a suave ondulado. O Cerrado é a vegetação natural nas 2 regiões. 
A despeito das maiores quantidades de nutrientes acumuladas, os clones produziram mais unidades de peso de biomassa por unidade de peso de $\mathrm{N}, \mathrm{P}, \mathrm{K}$ e $\mathrm{Mg}$ estocadas (maior eficiência de uso desses nutrientes) do que o povoamento propagado por sementes (pps). Por outro lado, o clone superior foi muito menos eficiente no uso de Ca relativamente ao pps. Mais de $90 \%$ das raizes finas dos genótipos pesquisados possuíam espessura $\leq 1 \mathrm{~mm}$. A distribuição e variação estacional da quantidade de raizes finas no perfil do solo apresentaram-se como características estreitamente relacionadas com a capacidade de adaptação dos genótipos aos estresses hídrico e térmico do solo, afetando diretamente seus potenciais produtivos. O clone superior (híbrido $E$. grandis vs. E. urophylla), genótipo mais produtivo, mostrou-se plástico, o clone inferior ( $E$. grandis) e o povoamento de E. grandis propagado por sementes, genótipos menos produtivos, mostraramse pouco plásticos às variações sazonais. A densidade de raízes finas ( $d r f$ na serapilheira foi muito superior àquela observada nas diferentes camadas de solo. No inverno, a drf $(<1 \mathrm{~mm})$ do clone superior foi de $6,5 \mathrm{~cm} \mathrm{~cm}^{-2}$ e $0,93 \mathrm{~cm}$ $\mathrm{cm}^{-3}$, na serapilheira e no solo $(0-10 \mathrm{~cm})$, respectivamente. Os genótipos menos produtivos apresentaram maior drf na serapilheira e nas camadas superficiais do solo, principalmente no verão. Parece que a disponibilidade de água é o principal fator a afetar a drf nas camadas mais profundas do solo $(>30 \mathrm{~cm})$ e a disponibilidade de nutrientes o principal fator a afetar a drf nas camadas superficiais do solo $(<30 \mathrm{~cm})$ e na serapilheira. Cada árvore do clone superior possuia, em média, cerca de $55 \mathrm{~km}$ de raízes finas $(<3 \mathrm{~mm})$, contra 32 $\mathrm{km}$ do genótipo propagado por semente. Para o clone inferior foi encontrado um valor médio de $40 \mathrm{~km}$ por árvore. Tudo indica que a extensão de raízes finas é uma característica intrínseca (fator hereditário) do genótipo, a qual é estreitamente relacionada com seu comportamento nutricional, potencial produtivo e capacidade de adaptação à condições de estresse ambiental. $O$ método do monolito para amostragem de raizes finas apresentou níveis de 
precisão similar aos obtidos com a sonda de $4 \mathrm{~cm}$ de diâmetro $(r=0,76$; $p<0,05)$. As sondas de 4 e $8 \mathrm{~cm}$ apresentaram níveis de precisão de amostragem semelhantes $(r=0,80 ; p<0,05)$. Os ganhos operacionais com 0 uso da sonda de menor diâmetro foram maiores em razão do fácil manuseio, o que possibilita aumentar o número de repetições. Além disso, a sonda de $4 \mathrm{~cm}$ é mais adequada do que a sonda de $8 \mathrm{~cm}$ de diâmetro para os solos mais arenosos (menos coesos), em virtude da menor perda e deformação das amostras de solo com raízes.

palavras-chave: raíz fina, eucalipto, clone, sistema radicular. 


\title{
CHARACTERISTICS OF EUCALYPT ROOT SYSTEM PROPAGATED BY SEED AND ROOTED CUTTING
}

\author{
Author: SERGIO LUIS DE MIRANDA MELLO \\ Adviser: Prof Dr. JOSÉ LEONARDO DE MORAES GONÇALVES
}

\section{SUMMARY}

The goals of this study were: (i) to compare sampling of fine roots with 4 and $8 \mathrm{~cm}$ of diameter augers (Area 1); (ii) to compare sampling of fine with auger and monolith method (Area 2); (iii) characterization of the fine root distribution in the soil profile, over summer and winter, of genotypes (Eucalyptus grandis Coff's Harbour and the hybrid E. grandis vs. E. urophylla) propagated by seed and rooted cutting (Area 2).

It was carried out in commercial stands of eucalypt, from 1994 to 1996 in Itatinga (Area 1) and Aguaí (Area 2) counties (State of São Paulo). The climate of the 2 regions is Cwa (Köppen classification). Cerrado is the native vegetation. Red-yellow Latosol, clayey, dystrophic, light wavy relief is the typical soil of the sites.

In spite of the higher amounts of accumulated nutrients, the clones produced more unites of biomass weight per unites of $\mathrm{N}, \mathrm{P}, \mathrm{K}$ and $\mathrm{Mg}$ uptaken (higher nutrient use efficiency) than seed propagated stands (sps). The superior 
clone was much less efficient in the use of $\mathrm{Ca}$ than sps. More than $90 \%$ of the fine roots from all studied genotypes had thickness $\leq 1 \mathrm{~mm}$. The fine root density (frd) in the litter was much higher than that founded in differents soil layers. Therefore, in the winter, the frd $(<1 \mathrm{~mm})$ of the best clone was $6.5 \mathrm{~cm}$ $\mathrm{cm}^{-2}$ and $0.93 \mathrm{~cm} \mathrm{~cm}^{-3}$ in the litter and superficial soil $(0-10 \mathrm{~cm})$, respectively. The less productive genotypes had higher (frd) in the litter and superficial soil layers, mainly in the summer. The data suggest that moisture availability is the main factor to affect the frd in deep soil layers (> $30 \mathrm{~cm}$ depth) and nutrient availability in superficial ones $(<30 \mathrm{~cm})$ and in the litter. The superior clone was more plastic than other genotypes. The monolith method had similar level of precision to that obtained with root sampling auger method $(r=0,76 ; p<0,05)$. The 4 and $8 \mathrm{~cm}$ of diameter root auger presented similar level of precision $(r=0,80 ; p<0,05)$. Consequently, using the thinner auger presented higher operational yield due its easier utilization and as consequence enables perform more experimental replications. Moreover, the root auger of 4 diameter was more suitable to sand soils, in reason of the lower deformation and lost of part soil cores with roots.

Key words: fine root, eucalypt, clone, root system. 


\section{INTRODUÇÃO}

A caracterização da distribuição do sistema radicular no perfil de solo, bem como sua variação estacional, são fundamentais para a definição e tomada de decisões a respeito de importantes práticas de manejo florestal, tais como o preparo do solo e recomendação de adubação (local e época de aplicação de adubos). Além disso, o conhecimento do sistema radicular das árvores constitui uma importante fonte de subsídios para explicar processos ecofisiológicos básicos, principalmente aqueles relacionados com a nutrição mineral e balanço hídrico de uma árvore ou de um povoamento florestal. A compreensão desses processos pode explicar, por exemplo, diferenças entre genótipos quanto suas adaptabilidades à diferentes condições de estresse ambiental, portanto, constituindo uma ferramenta imprescíndivel para o melhoramento florestal.

Analisando as pesquisas desenvolvidas no Brasil, relativas a estudos sobre o sistema radicular das árvores, constata-se que a principal ênfase tem sido dada ao sistema radicular de sustentação, envolvendo árvores individuais, as quais têm suas raizes finas descartadas. Os principais trabalhos que englobaram estudos sobre o sistema radicular de absorção foram desenvolvidos por Reis et al. (1985 e 1987) e Gonçalves (1994). Estes autores verificaram grande efeito das condições climáticas, das características físicas e quimicas do solo e da produtividade de florestas de eucaliptos sobre a 
quantidade e distribuição de raízes de absorção no perfil de solo. Segundo Böhm (1979) e Persson (1983) os estudos sobre o sistema radicular de absorção são, de modo geral, muito escassos e apresentam muitas limitações, como por exemplo: amostragem inadequada e restrita à poucas estações do ano ou periodos de tempo curtos, separação, quantificação e classificação de raízes vivas e mortas precárias ou inexistentes. Dentre as principais dificuldades para se estudar o sistema radicular das árvores, destacam-se: a grande demanda de mão-de-obra, os elevados custos e tempo de execução dos trabalhos (Böhm, 1979).

Nesse contexto, foram objetivos do presente estudo: (i) comparar a amostragem de raízes finas com sondas de 4 e $8 \mathrm{~cm}$ de diâmetro (Área 1); (ii) comparar a amostragem com sondas e o método do monolito (Área 2); (iii) caracterizar a distribuição das raízes finas no perfil de solo, no verão e inverno, de materiais genéticos (Eucalyptus grandis (Coff's Harbour) e do híbrido $E$. grandis vs. E. urophylla) propagados por sementes e enraizamento de estacas (Área 2). 


\section{REVISÃO BIBLIOGRÁFICA}

\subsection{Classificação das raízes finas}

Do ponto de vista funcional, as raizes finas ou de absorção, são aquelas que apresentam intensa atividade metabólica, tendo como principal atribuição fisiológica a absorção de água e nutrientes. As raízes de sustentação, bem mais espessas e suberificadas, são aquelas responsáveis pelo suporte estrutural das árvores e pela condução de soluções entre o sistema radicular e a parte aérea.

O critério mais utilizado para a classificação de raizes finas se baseia na espessura das raízes; principalmente em estudos sobre a avaliação da biomassa radicular. Na literatura, é possivel encontrar o uso de $5 \mathrm{~mm}$ como limite superior da classe das raízes finas (Santantonio, 1977; Fogel, 1980, Meier et al., 1985); no entanto, as espessuras mais utilizadas estão entre 2 e 3 mm (Aber et al., 1985; Powell \& Day, 1991). Raízes muito finas é uma denominação dada a raízes com diâmetro menor que $1 \mathrm{~mm}$ (Berish \& Ewel, 1988; Löhmus \& Ivask, 1995) ou <0,5mm (Nambiar, 1987). Pode-se citar ainda as raizes finíssimas ou tipo 'cabeleira', as quais ocorrem em regiōes restritas do solo (com acúmulo de material orgânico) as quais apresentam de 5 a $17 \mu \mathrm{m}$ de diâmetro (Sutton, 1980). A definição de classes de diâmetro ainda possibilita interpretar alguns aspectos da dinâmica populacional de raizes finas, como por exemplo, a taxa de renovação e a ciclagem de nutrientes. 
Neste trabalho, o critério fisiológico é empregado na distinção da classe de raizes finas, as quais possuem diâmetro inferior a $3 \mathrm{~mm}$, não apresentando espessamento do xilema secundário e possuindo floema pouco desenvolvido, conforme estudo realizado por Lyford (1975). Outros autores também já adotaram esta classificação (Moir \& Bachelard, 1969; Santantonio et al., 1977; Gonçalves, 1994; Aber et al., 1985).

\subsection{Biomassa de raízes finas}

Devido à facilidade de obtenção dos dados a partir da biomassa da parte aérea, são inúmeros os trabalhos que tratam do assunto, onde a biomassa radicular não é considerada ou então se tenta estimá-la a partir de dados da parte aérea da planta. Uma estimativa satisfatória da biomassa de raizes finas foi obtida a partir de modelos que contemplam a idade, altura e o diâmetro a altura do peito (dap) como variáveis independentes (Reis et al., 1985; Negi \& Sharma, 1987). Contudo, variações nas características de diferentes sítios podem reduzir significativamente a eficácia para o uso geral destes modelos.

A alocação da biomassa e nutrientes entre os diferentes compartimentos da árvore depende do genótipo, idade, características do sítio e das práticas silviculturais empregadas (Safford, 1974; Keyes \& Gries, 1981; Miller, 1986). Santantonio et al. (1977) obtiveram um porcentual de biomassa radicular que variou de 14 a $52 \%$ em florestas de coníferas e decíduas. Westman \& Rogers (1977) verificaram que as raizes correspondiam a $43,5 \%$ da biomassa de árvores em florestas naturais com predominância de Eucalyptus signata e Eucalyptus umbra. Esta contribuição mais expressiva de raizes é resultado de um longo período evolutivo, no qual as espécies mais adaptadas desenvolveram uma estratégia de maior alocação relativa de 
biomassa radicular, permitindo um suprimento adequado de água e nutrientes em condições adversas.

No entanto, alterações na alocação de carbono para as raízes se devem em grande parte ao estado hídrico e nutricional do solo (Keyes \& Grier, 1981; Persson, 1983). O desenvolvimento da biomassa radicular em povoamento de Eucalyptus globulus em diferentes tipos de solos foi objeto de estudo de Fabião et al. (1987). Os autores concluíram que a quantidade e a distribuição de biomassa de raizes ao longo do perfil do solo foi muito dependente da textura do solo e disponibilidade de água e nutrientes. Ao estudarem o acúmulo de biomassa em povoamentos de Eucalyptus grandis, Reis et al. (1985) observaram que no decorrer do tempo o acúmulo de biomassa radicular foi aproximadamente 2 vezes maior no solo mais pobre (4417 $\mathrm{kg} \mathrm{ha}^{-1}$ ) quando comparado a outro mais fértil (1692 kg ha-1). Neste mesmo trabalho, constatou-se que a biomassa radicular era de 34 e $13 \%$ da biomassa total no pior e melhor sítio, respectivamente. Resultados similares foram relatados por Keyes \& Grier (1981) onde encontraram um valor 2,5 vezes maior de raízes finas em solos pobres em relação à solos férteis, sob povoamentos de Pseudotsuga mensiesii com 40 anos de idade. Tal fato foi justificado pela maior alocação de fotoassimilados para a formação de raízes de absorção e elevação do volume de solo explorado. Os solos com reduzidos estoques de água e nutrientes apresentam uma produção relativa de biomassa da parte aérea notadamente inferior, quando comparada àquela de um solo fértil, considerando-se a mesma espécie e práticas silviculturais idênticas. Isto ocorre porque considerável quantidade de fotoassimilados são destinados à formação de biomassa radicular.

Num estudo de desenvolvimento do sistema radicular de Pinus radiata, Nambiar (1987) observou que apesar do reduzido número de raízes maiores que $1 \mathrm{~mm}$ de diâmetro, a variação de peso e distribuição ao 
longo do perfil do solo mostraram-se significativos. Notou também que o peso de raizes grossas dobrou e o comprimento se manteve praticamente constante, fato este relacionado com o espessamento de raizes laterais para dar sustentação à árvore. É oportuno mencionar que, ao se realizar a avaliação da biomassa radicular num determinado momento, a quantidade de raízes finas é relativamente pequena. No entanto, quando se pensa na elevada taxa de renovação das raízes finas durante o ciclo de vida de uma árvore, é possível deduzir que a biomassa de raízes finas produzida é bastante significativa. Assim, a estimativa da biomassa radicular é fundamental na compreensão da dinâmica presente nos ecossistemas florestais, envolvendo o fluxo de água e nutrientes. Na prática, o entendimento deste mecanismo pode ser alcançado a partir da quantificação periódica da biomassa total das árvores, assim como dos processos de entrada (adubação, precipitação, fixação biológica, poeira) e saída (erosão, lixiviação, volatilização, colheita florestal).

\subsection{Distribuição das raízes finas}

O conhecimento detalhado sobre a formação e distribuição das raízes é essencial na busca de uma harmoniosa relação entre o sistema radicular e as intervenções realizadas no solo. É fundamental que se leve em consideração a configuração do sistema radicular, quando na tomada de decisão quanto às práticas silviculturais, dentre as quais estão a época e local de aplicação do adubo. Além disso, estudos que tratam da demanda de água e nutrientes pelas árvores deveriam estar diretamente associados ao estudo de raízes de absorção.

A distribuição vertical de raízes depende de vários fatores, onde podem ser incluídos o tipo de solo (Davis et al., 1983), teor de água e nutrientes no solo (Axelsson \& Axelsson, 1986; Ahlström et al., 1988; Fabião et al., 1995), temperatura (Bowen, 1970; Deans, 1979), aeração, quantidade de 
material orgânico (Ford \& Deans, 1977), compactação (Sands et al. 1979; Greacen \& Sands, 1980, Kemper \& Derpsch, 1981; Camargo, 1983, Borges et al., 1986). Todos esses fatores interagem com as características intrínsecas, ou seja, o genótipo da espécie, resultando numa arquitetura radicular única para cada árvore. A contribuição relativa destes fatores sobre a distribuição radicular só pode ser conseguida através de um bom controle experimental.

A maioria dos trabalhos tem mostrado que significativo montante da biomassa radicular se encontra nas camadas superficiais do solo e na serapilheira (Roberts, 1976; Carbon et al., 1980; Feller, 1980; Nambiar, 1983; Gonçalves, 1994; Leles, 1995). Segundo Davis et al. (1983), a distribuição vertical de raízes em povoamentos de Pinus radiata, aos 12 anos de idade, foi fortemente influenciada pelas caracteristicas físicas e químicas de diferentes tipos de solos. Os autores encontraram $61 \%$ das raízes entre 20 e $80 \mathrm{~cm}$ no solo mais arenoso ("krasnozem") e apenas $25 \%$ abaixo de $20 \mathrm{~cm}$ de profundidade no solo mais argiloso (podzólico). Ao avaliar as características do sistema radicular de povoamentos de Eucalyptus grandis em diferentes tipos de solos, Gonçalves (1994) encontrou maior densidade de raizes finas nos sítios menos férteis; contudo, a distribuição de raízes ao longo do perfil do solo não foi diferente entre os diferentes os sítios, registrando cerca de $60 \%$ nos primeiros $30 \mathrm{~cm}$.

Em povoamentos de Eucalyptus globulus verifica-se que a distribuição de raizes finas localiza-se nos horizontes superficiais do solo (inclusive na manta orgânica), em torno de 0 a $30 \mathrm{~cm}$, assumindo grande importância na demanda de água e nutrientes, com destaque aos elementos $\mathrm{N}$ e P (Fabião et al., 1985). A distribuição vertical de raízes entre as espécies de eucaliptos é bastante variável. Dentre as centenas de espécies de Eucalyptus spp, são citadas a seguir apenas as principais estudadas. $O E$. cloeziana e o $E$. microcorys desenvolvem um sistema radicular mais superficial; no outro 
extremo, o E. camaldulensis, E. tereticornis e E. citriodora apresentam grande aprofundamento das raizes no perfil do solo. Outro grupo maior apresenta características intermediárias (E. pellita, E. robusta, E. resinifera, E. saligna, $E$. urophylla, E. dunii e E. grandis). A partir de diversos estudos destas espécies, concluiu-se que a distribuição do sistema radicular está sobretudo associado ao tipo de copa da árvore; em suma, à própria ecofisiologia da espécie.

A compactação do solo, decorrente da intensificação da mecanização e, aliada ao manejo inadequado do solo, tem motivado a avaliação de seus efeitos sobre o sistema radicular. Borges et al. (1986) avaliaram o efeito de diferentes níveis de compactação do solo em vasos plantados com eucaliptos. Eles observaram que, em densidade superior a 1,25 $\mathrm{g} \mathrm{cm}^{-3}$, o crescimento radicular foi reduzido ou nulo. Greacen \& Sands (1980) constataram que parte da compactação pode ser atribuída ao próprio peso das árvores, em determinados povoamentos florestais.

A distribuição lateral de raízes é função do potencial genético e, sobretudo, decorrente de práticas silviculturais como o tipo de preparo (Ford \& Deans, 1977, Mello, 1992), forma de aplicação do adubo, tipo e frequência de capinas, espaçamento de plantio (Leles, 1995), dentre outros. Em povoamentos jovens, a distribuição horizontal de raizes está fortemente condicionada à estas práticas de manejo. No entanto, estes efeitos parecem desaparecer com a idade do povoamento; contudo, mantendo uma tendência de maior crescimento próximo ao tronco (Roberts, 1976; Davis et al.,1983; Baldwill \& Stewart, 1987).

Com a redução do espaçamento de plantio, Leles (1995) observou uma tendência de maior concentração de raízes finas mais próximo da árvore, em povoamentos de Eucalyptus camaldulensis e E. pellita, aos 52 meses de idade. Em espaçamentos menores, houve também uma redução na 
produção de biomassa da parte aérea das árvores, o mesmo se refletindo na biomassa radicular. Assim, com menor peso das árvores para se ancorar, além da menor exposição ao vento, é muito provável que tenha ocorrido uma redução significativa da concentração de raízes mais espessas.

As atividades conjugadas de preparo do solo e adubação reduzem os custos operacionais. Contudo, o contato entre as raízes das mudas e 0 adubo dependende da sua solubilidade e localização, principalmente em solos arenosos. Visando quantificar o melhor período e localização da adubação nitrogenada e potássica, de cobertura, em povoamento de Eucalyptus grandis, Stape (1990) desenvolveu um modelo onde a distância de aplicação do adubo está em função da altura média das mudas no campo, nas quais se determinou o alcance das raízes. $O$ aproveitamento da adubação é dado pela relação entre o fertilizante que está dentro do alcance das raízes e o fertilizante total aplicado. Portanto, a compreensão destes mecanismos que atuam na interface solo-raíz são relevantes para o meio científico e contribuem para o aperfeiçoamento das técnicas de manejo do solo.

A distribuição de raízes na superfície do solo também pode ser influenciada pelo tipo e intensidade de precipitação incidente. Ford \& Deans (1978) observaram em plantios adultos (14 anos) de Picea sitchensis, que a distribuição de raízes finas foi coincidente com a projeção de distribuição da precipitação interna, que equivale a $43 \%$ da precipitação total nas condições deste trabalho. Tal fato foi explicado, em grande parte, devido a arquitetura da copa desta espécie. Reynolds (1970) observou alta concentração de raízes finas próximas ao tronco das árvores de um povoamento de Pseudotsuga taxifolia aos 36 anos de idade, a qual foi em grande parte atribuída ao escoamento de água pelo tronco. É preciso observar que a copa e o volume de troncos das árvores adultas se tornam importantes interceptadores e condutores de água provenientes das chuvas. 


\subsection{Fatores que afetam o crescimento das raizes finas}

O crescimento de raízes finas pode ocorrer independentemente ou não da parte aérea (Persson, 1983; Raich \& Nadelhoffer, 1989). Os fatores determinantes do crescimento radicular são complexos e envolvem o estado nutricional, disponibilidade de oxigênio no solo, hormônios de crescimento, suprimento de carboidratos e sua alocação relativa na raíz e parte aérea, que se traduzem por expressões singulares de seu material genético, e ao mesmo tempo associados às condições do meio ao qual toma parte. Ao estudar a distribuição e produtividade de raízes finas em florestas boreais, Persson (1983) notou que em solos pobres há uma tendência de crescimento de raízes longas, as quais ocupam grande volume de solo ao longo de seu perfil. Por outro lado, a ocorrência de numerosas raízes curtas, geralmente associadas a micorrizas, é comum em solos férteis ou na manta orgânica existente sobre o solo.

A temperatura do solo e do ar são importantes reguladores da atividade radicular. Nambiar (1983) constatou um incremento maior do comprimento em relação ao peso de raízes de Pinus radiata, quando a temperatura do solo era superior a $15^{\circ} \mathrm{C}$, e que o crescimento e regeneração de raízes apresentou uma estreita relação com o teor de água no solo. $O$ mesmo autor também verificou que a compactação do solo influiu na distribuição de raizes, mas não no crescimento radicular. Para Fabião et al. (1995), o crescimento radicular decresce drasticamente com a adubação e particularmente com a fertirrigação, o que não se observou com raízes grossas (maiores que $5 \mathrm{~mm}$ de diâmetro). Uma provável redução na deposição de folhedo deve ter ocorrido, contudo não foi mencionada no trabalho. A radiação solar também está diretamente relacionada ao crescimento radicular (Roberts, 
1976), a qual é a fonte de energia para a produção de fotoassimilados produzidos nas folhas e alocados no sistema radicular.

A estabilização do crescimento radicular parece acompanhar a redução da taxa de crescimento da parte aérea (Eis, 1974, Squire et al., 1978). Squire et al. (1978) encontraram uma concentração máxima de $0,20 \mathrm{~cm} \mathrm{~cm}^{-3}$, obtida aos 8 anos para um plantio de Pinus radiata. Assim, em povoamentos de Eucalyptus spp, a densidade máxima de raízes pode ocorrer quando a taxa de crescimento da parte aérea se estabiliza. Outros estudos indicam que o fechamento de copa coincide com a estabilização na produção de biomassa de raízes finas (Moir \& Bachelard, 1969; Vogt et al., 1981;Berish \& Ewel, 1988). É neste período em que se inicia a competição entre árvores por água e nutrientes e, principalmente por luz, particularmente no caso das espécies menos tolerantes ao sombreamento, como é o caso do Eucalyptus grandis.

A senescência de raízes finas é atribuída às condições estressantes decorrentes de variações estacionais de temperatura, disponibilidade de água, ou por injúria à copa (desfolhamento, parasitismo) ou mesmo por alterações hormonais. As relações entre o sistema radicular e a parte aérea não consistem simplesmente de uma troca de água e nutrientes inorgânicos e orgânicos; sabe-se da existência de um mecanismo muito mais complexo, que envolve niveis adequados de determinados hormônios que atuam como reguladores de crescimento, onde o sistema radicular é o principal sítio de produção de alguns deles. As raízes finas constituem estruturas efêmeras e com uma taxa de renovação comparável às folhas; desta forma, é possível se esperar um padrão de resposta em comum diante dos fatores ambientais. 


\subsection{Raízes finas e absorção de nutrientes}

Segundo Russel et al. (1981), os principais macronutrientes ( $N, \mathrm{P}$ e K) podem ser absorvidos por qualquer parte do sistema radicular; o $\mathrm{Ca}$ é absorvido quase que totalmente através de raízes não suberificadas, onde também a absorção de água é muito mais efetiva (fluxo de massa). Contudo, somente uma pequena parte desta água é utilizada em suas atividades metabólicas, cuja maior demanda decorre do processo de transpiração como consequência das trocas gasosas necessárias à atividade fotossintética. A quantificação da extração de água do solo pelas árvores pode ser prevista através da elaboração de modelos (Jon Van Lier, 1994).

Fabião et al. (1995) notaram que, após 6 anos do plantio, as diferenças na produção de biomassa radicular entre os povoamentos de Eucalyptus globulus fertilizados e não fertilizados tenderam a se reduzir com a idade. É provável que com o aprofundamento do sistema radicular com a idade, a maior disponibilidade de água existente em profundidade passa a ser 0 principal fator que regula o crescimento radicular e conseqüentemente de toda a árvore.

Além da absorção de nutrientes, as raízes finas intercambiam os processos de transferência micorrizas-árvore, especialmente quanto a incorporação de P (Sanni, 1976). Persson (1980) verificou que a presença de infecções micorrizicas reduziu significativamente a taxa de renovação de raízes finas, uma vez que prolongou sua atividade fisiológica. Por outro.lado, a frequência micorrízica é drasticamente reduzida quando o déficit hídrico se instala (Ashton, 1976), uma vez que a maior número de raízes micorrizadas se encontra nas camadas superficiais, mais suceptiveis às condições adversas do meio. Em povoamentos de eucaliptos, as ectomicorrizas estabelecem, de modo geral, as principais associações com as raízes finas. As raízes micorrizadas 
estão sendo amplamente estudadas, onde se busca uma melhor compreensão de sua dinâmica e efetiva participação na ciclagem de nutrientes.

\subsection{Taxa de renovação de raízes finas}

A taxa de renovação de raízes finas está condicionada a reações hormonais e fisiológicas diante de condições estressantes e de ocorrência sazonal. A retranslocação de nutrientes a partir das raízes finas também faz parte deste mecanismo (Meier et al., 1985; Nambiar, 1987). Meier et al. (1985) afirmaram que, dependendo da idade do povoamento de Abies amabilis, a redistribuição interna no sistema radicular equivale, em média, a 45 e $60 \%$ da demanda de $\mathrm{N}$ e $\mathrm{P}$, respectivamente, para o crescimento de raízes finas.

Reynolds $^{1}$, citado por Fogel (1983) comentou que a manutenção de uma pequena quantidade de raízes poderia ser desvantajoso, devido ao alto custo energético, diante de uma condição ambiental desfavorável. Diante disso, existe uma estreita relação entre o custo de energia no desenvolvimento e manutenção do sistema radicular e sua efetiva função como órgão de absorção e transporte de água e nutrientes.

${ }^{1}$ REYNOLDS, E. R. C. Tree rootlets and their distribution. In: TORREY, J. G. \& CLARKSON, D. T. The Development and Function of Roots. Academic Press, London,. p.163-177, 1975. 
Harris ${ }^{2}$, também citado por Fogel (1983) justificou um aumento da taxa de renovação de raízes finas como uma estratégia adaptativa onde haveria a imobilização microbiana, evitando a perda de nutrientes no período em que vigoram os fatores estressantes.

Uma hipótese também foi apresentada por Persson (1983), na qual um solo sob uma floresta é parcialmente umidecido, estabelece-se uma restrita zona de crescimento de novas raízes ao longo do ápice radicular. Contudo, sua curta duração se consuma com o esgotamento da solução do solo e a inativação (suberização), senescência e morte das raízes. O material radicular imobiliza os nutrientes temporariamente, até que, em condições favoráveis, se inicie o processo de mineralização dos nutrientes constituintes, os quais novamente suprem esta zona de crescimento radicular.

A variação temporal da distribuição e quantidade de raízes deve ser considerada quando se avalia a distribuição espacial de raízes finas. Assim, por exemplo, a variação na densidade de raízes finas obtida numa amostragem no inverno e outra no verão pode ser superior à amostragem de raízes em sítios diferentes (Persson, 1983).

2 HARRIS, W. F.; SANTANTONIO, D. \& McGINTY, C. The dynamic belowground ecossystem. In: WARING, R. H. Forest: Fresh Perspectives from Ecosystem Analysis. Oregon, St. Univ. Press. Corvallis, p.119-129, 1980. 
Com isto, torna-se bem evidente a importância da amplitude destas variaçōes sazonais como consequência do regime de chuvas, temperatura, condições edáficas e da cobertura vegetal. Santantonio et al. (1977) não obtiveram diferenças sazonais significativas quanto à biomassa radicular de coníferas; por outro lado, Fogel (1979) e outros pesquisadores observaram o contrário (Ford \& Deans, 1977; Persson, 1980). Isto ocorre porque a taxa de renovação de raizes finas é muito variável. Na prática, o monitoramento da taxa de renovação de raízes finas é muito difícil, resultando em poucos, mas importantes trabalhos disponiveis na literatura. Dentre estes, pode-se citar o trabalho de Persson (1983), no qual utilizou o método de amostragem sequencial de colunas de solo ("cores") e a medição do crescimento interno de novas raízes dentro destas contendo areia para avaliar a produção de raízes finas, com coletas em intervalos regulares. Neste trabalho, o autor constatou uma menor taxa de renovação de raízes finas na camada superficial do solo (0$10 \mathrm{~cm}$ ) e na serapilheira. A coleta de amostras volumétricas de solo é a forma mais simples de se estudar o efeito das variações sazonais sobre o crescimento radicular, o qual é recomendado para solos arenosos. Outra possibilidade para o estudo da dinâmica de crescimento de raízes é o emprego de "minirhizotrons", em outras palavras, equipamentos de endoscopia para a filmagem das raízes ao longo do tempo, dentro de tubos introduzidos no solo (Taylor et al., 1990). Recentemente, novas técnicas não destrutivas para o estudo do sistema radicular tem sido aperfeiçoadas, dentre as quais se destacam o uso de raio $X$, imagens de ressonância magnética (Macfall et al., 1991) e a tomografia computadorizada (Tollner et al., 1994). Estas técnicas são uma grande conquista para se compreender a dinâmica existente no sistema radicular, pois permitem monitorar o estado fisiológico das raízes ao longo do tempo. 


\subsection{Raízes finas e a mineralização de nutrientes}

O papel de raízes finas e micorrizas na dinâmica da ciclagem de nutrientes foram negligenciados nos últimos 30 anos de pesquisa, restringindo-se sobretudo ao estudo do sistema radicular de árvores individuais, desconsiderando as interações existentes no ecossistema florestal. Juntamente com a serapilheira, as raízes finas senescentes são a principal fonte de material orgânico para o complexo ciclo de decomposição que ocorre no solo. Muitos pesquisadores assumem que a dinâmica de crescimento de raízes finas é muito similar àquela da parte aérea; no entanto, não há evidências disto, nem mesmo para a mesma espécie. Além disso, há também as interações intra e interespecíficas, estabelecendo a competição por água $e$ nutrientes. A produção e ciclagem de raízes finas são de grande importância ao processo de ciclagem de nutrientes, assim como no incremento do teor de matéria orgânica ao longo do perfil do solo. Com teores de nutrientes próximos aos encontrados nas folhas, as raízes finas desempenham papel de igual magnitude na ciclagem de nutrientes. Enquanto a deposição de folhedo promove a liberação de nutrientes nas camadas mais superficiais, a decomposição de raizes de absorção, ricas em nutrientes, formam no solo microrregiões mais férteis, que posteriormente são ocupadas por novas raízes. Em florestas de coníferas, as raízes finas liberam duas vezes mais $\mathrm{N}$ que 0 folhedo, considerando o mesmo período de tempo (Fogel, 1980). Mcclaugherty et al. (1982) avaliaram a contribuição de raizes finas de povoamentos adultos de Pinus resinosa e "hardwoods" sobre os estoques de $\mathrm{N}$ e na quantidade de matéria orgânica, onde o peso seco de raízes vivas era em média maior em povoamentos de "hardwoods" $\left(6,6 \mathrm{t} \mathrm{ha}^{-1}\right)$, em relação ao Pinus resinosa $(5,1 \mathrm{t}$ ha $^{-1}$ ), o mesmo ocorrendo com a concentração de $\mathrm{N}$ no tecido radicular $(65 \mathrm{~kg}$ $\mathrm{ha}^{-1}$ e $42 \mathrm{~kg} \mathrm{ha}^{-1}$, respectivamente). Os autores concluíram que grande parte da produção anual esteve associada com a baixa razão de decomposição de raízes finas, indicando que uma considerável fração do teor de $\mathrm{N}$ e matéria 
orgânica do solo provêm destas. Em povoamentos de eucaliptos, o sistema radicular pode contribuir com 25 a $34 \%$ do nutrientes, sobretudo em solos mais pobres (Reis et al., 1987). Este mecanismo pode ser entendido como uma estratégia adaptativa, onde elevadas taxas de renovação de raízes finas representam um considerável custo energético às árvores que, em contrapartida, intensificam as qualidades desejáveis ao solo. Gonçalves (1994) verificou que nas raízes finas de Eucalyptus grandis ficam locados cerca de 9,$4 ; 1,5 ; 5,1 ; 5,6$ e $2,1 \mathrm{~kg} \mathrm{ha}^{-1}$ de $\mathrm{N}, \mathrm{P}, \mathrm{K}, \mathrm{Ca}$ e $\mathrm{Mg}$, respectivamente. De posse destas concentrações de nutrientes, é possivel prever que uma significativa quantidade é ciclada anualmente pelo processo de renovação de raízes finas. Yin \& James (1991) elaboraram uma análise de regressão múltipla a partir dos fatores que afetam a concentração do $\mathrm{N}$ em raizes de absorção de comunidades florestais, verificando que $93,2 \%$ das variações para este elemento estiveram associadas ao diâmetro radicular, temperatura mínima (média) mensal, origem da floresta e tipo florestal. A partir do momento que se quantificam raízes de maior diâmetro, a participação de tecidos mais 'velhos' aumenta e passam a predominar elementos com finalidade estrutural $(\mathrm{Ca}, \mathrm{Mg}$ e N).

Ao se avaliar a distribuição de carbono e o fluxo de $\mathrm{N}$ após o corte raso em plantios de Pinus radiata, comparado a floresta adulta, Smethurst \& Nambiar (1990) observaram que o aumento da taxa de mineralização estava associada à elevação da temperatura e redução drástica da demanda de N. Os autores comentaram que não foi analisada a contribuição das raizes mortas após o corte raso da floresta nas taxas de mineralização, mas admitiram que pode afetar de forma significativa os "inputs" de $\mathrm{N}$ mineralizável no solo. Fogel (1980) também comentou que a mortalidade e decomposição de raízes finas é o mais importante dos mecanismos de retorno do $\mathrm{N}$ imobilizado das árvores ao solo em florestas decíduas e de coníferas. Numa revisão, o autor constatou que, em povoamentos de coníferas, $21 \%$ do $\mathrm{N}$ das árvores é encontrado nas 
raízes finas. Persson (1983) constatou que em solos florestais úmidos há mais raízes vivas que mortas, enquanto que em povoamentos florestais em solos secos ocorre o contrário. Nestas condições, as raízes mortas, além de aumentarem a capacidade de retenção de água no solo, enriquecem o fluxo de nutrientes via mineralização. Entretanto, estes estudos "in situ" são muito dificeis, o que se entende por um desafio inerente à pesquisa do sistema radicular. Para que se tenha uma idéia da dinâmica de raízes finas, é fundamental que se realizem amostragens durante mais de um período sazonal, utilizando-se de técnicas apropriadas para o monitoramento de todas as etapas de "morte" de raízes, imobilização e liberação de nutrientes disponíveis às árvores.

\subsection{Raízes e seus efeitos sobre o solo}

Existem parâmetros que são excelentes indicadores das condições do solo, como a presença de grande quantidade de canais formados pelas raizes e por organismos no solo. Em regiões onde há maior acúmulo de raízes finas, associadas ou não à micorrizas, já foi comprovada a liberação de polissacarideos que aumentam a estabilidade dos agregados no solo (Singhal \& Dev,1977); contudo este equilíbrio pode ser breve quando se adotarem práticas inadequadas de manejo do solo. $O$ crescimento radicular contribui para a redistribuição da matéria orgânica e nutrientes no perfil do solo (Sá, 1993). As raizes finas vivas podem estimular a decomposição de material orgânico e raízes senescentes, as quais geralmente se encontram associadas à micorrizas (Robinson, 1989).

A biomassa de raízes finas exerce significante influência nas propriedades de solos pobres, elevando o teor de matéria orgânica quando de sua "morte" e disponibilizando nutrientes prontamente assimiláveis pelas raízes novas que tomam seu espaço físico no solo. As raizes finas exercem uma forte 
influência no perfil do solo; quando 'morrem', contribuem para a elevação dos teores de matéria orgânica ao longo do perfil do solo. Davis et al. (1983) encontraram uma forte correlação entre a concentração de raízes finas de Pinus radiata e o teor de matéria orgânica $(r=0,70$ à 0,$97 ; P<0,01)$ em 5 sítios florestais distintos, enquanto que o elemento $\mathrm{Ca}$ correlacionou bem onde a correlação desse com a matéria orgânica também era elevada. Neste mesmo trabalho, os autores observaram uma tendência das raízes finas se desenvolverem ao longo dos canais provenientes da decomposição das raízes senescentes. Recentes estudos indicam que o sistema radicular de absorção é responsável pela maior parte do carbono ciclado nos ecossistemas florestais (Fogel,1980; Persson, 1983; Hendrickson \& Robinson, 1984) e importante fonte de carbono para o solo (Mcclaugherty et al, 1982; Fabião et al., 1995).

\subsection{Amostragem de raizes finas}

\section{Amostragem pelo método do monolito}

A raiz é a parte menos estudada das plantas, sobretudo devido às dificuldades operacionais e carência de uma metodologia prática e confiável para seu estudo in situ. As primeiras avaliações do sistema radicular foram efetuadas através do uso de métodos muito laboriosos, onde se destaca o método do monolito, considerado o método padrão para estudos quantitativos do sistema radicular (Böhm, 1979; Köpke, 1981). O método consiste da retirada de blocos de solo, ou monolitos, do interior de trincheiras. A seguir, os monolitos são lavados com água sob peneiras, com a finalidade de separar as raízes contidas nos monolitos das partículas de solo. Em solos mais argilosos, torna-se necessário o uso de agentes dispersantes para separar as partículas de solo, fortemente aderidas às raizes (Böhm, 1979). O método tem como vantagem a maior exatidão na estimativa dos parâmetros radiculares. Porém, 
em virtude da grande variabilidade espacial das raízes, o método do monolito mostra-se pouco preciso.

\section{Amostragem com sondas}

A coleta de raízes de absorção com sondas já é empregada e recomendada para uso em florestas, o que se pôde comprovar a partir de extensa revisão sobre 0 assunto. $O$ uso de sondas permite intensificar os estudos do sistema radicular e seu monitoramento em povoamentos florestais, uma vez que possibilita coletar um grande número de amostras sem destruir a área amostrada. Trabalhos existentes na literatura citam o uso de sondas de $1,9 \mathrm{~cm}$ (Mcclaugherty et al., 1982), até de $15 \mathrm{~cm}$ de diâmetro, operadas através de potência hidráulica (Boehle et al., 1963; Davis et al., 1983). Estas variações do diâmetro das sondas se justificam quanto aos usos particulares em cada trabalho, às condições do solo (Persson et al., 1995), disponibilidade de tempo e recursos, quanto ao número de amostras e volume de material necessário ao estudo. Em locais e/ou compartimentos do perfil do solo com menor ocorrência de raízes finas, torna-se necessário o uso de sondas de maior diâmetro, ou então aumentar o número de repetições. Böhm (1979) recomenda o emprego de sondas de $7 \mathrm{~cm}$ de diâmetro, com a qual uma anóostragem com 5 repetições é suficiente; no entanto, quando se espera uma concentração de raízes reduzida, recomenda-se realizar uma análise estatística com a finalidade de se determinar o número mínimo de amostras necessárias para um determinado nivel de probabilidade. Vários pequisadø̆res já utilizaram sondas para a amostragem de raízes (Moir \& Bachelard, 1969; Roberts, 1976; Ford \& Deans, 1977; Santantonio et al., 1977; Persson, 1980; Hendrickson \& Robinson, 1984; Aber et al., 1985; Berish \& Ewel, 1988; Adams et al. 1989; Powell \& Day, 1991; Neave \& Florence,1994 e Majdi et al., 1995) 
Mcclaugherty et al. (1982) obtiveram resultados similares utilizando sondas de 19 e $50 \mathrm{~mm}$ de diâmetro, optando pelo uso da sonda de menor diâmetro, que demandou menor tempo e trabalho de processamento das amostras. Roberts (1976) confeccionou trincheiras rente às perfurações efetuadas com sondas, certificando-se que as raízes estavam sendo adequadamente cortadas pela ponta da sonda, sem ocorrência de maceração das mesmas. Bragg et al. (1983) realizaram uma comparação de 3 métodos de estudo da distribuição e crescimento de raízes finas: "minirhizotron" instalado na vertical no solo, "minirhizotron" instalado no solo num ângulo de $45^{\circ} \mathrm{e}$ amostragem com sonda de $7 \mathrm{~cm}$ de diâmetro e posterior lavagem em peneira com vão de $0,5 \mathrm{~mm}$. Os autores concluíram que o método do "minirhizotron" instalado no solo num ângulo de $45^{\circ}$ apresentou um padrão similar ao comprimento obtido pela amostragem com sonda, demonstrado a partir de uma alta correlação entre os mesmos. Em outros trabalhos, a combinação de método de escavação e "minirhizotron" foram mais promissores para se estimar a biomassa radicular e sua dinâmica sazonal.

$\mathrm{Na}$ estimativa dos parâmetros radiculares utilizando-se da amostragem com sondas, a partir de diferentes trabalhos, nota-se a dificuldade de compará-los em função das diferentes maneiras de separar as raízes do solo. Outras limitações são a profundidade amostrada, estádio fisiológico do povoamento, idade, número de árvores por hectare, tamanho e classificação das raízes e, sobretudo, pela comprovada variação na eficiência dos diferentes métodos existentes. Os métodos de estudos de raízes finas apresentados na literatura são escassos e requerem um aperfeiçoamento e padronização para que se possa confiar nos resultados obtidos através destes. Persson (1983) citou as limitações em estudos do crescimento radicular em ecossistemas florestais: a) o número insuficiente de amostragem durante o periodo sazonal; b) a biomassa de raízes finas inclui um número desconhecido de raízes mortas; c) os fragmentos de raízes finas mortas não são estimados; d) o número de 
repetições é insuficiente para detectar diferenças significativas entre as amostras; e) a amostragem de raízes finas não é coletada numa mesma área ao longo do tempo e f) os fragmentos de raizes não são classificados em classes diamétricas.

\subsection{Separação de raízes finas}

Fogel (1983) ao comparar o método de seleção manual de raizes finas com o peneiramento com água, verificou que houve 30 a $40 \%$ de incremento de biomassa de raízes de diâmetro inferior à $2 \mathrm{~mm}$ quando se utilizou o peneiramento com água, enquanto que a seleção manual foi apenas adequada quando aplicada para raízes de 2 à $5 \mathrm{~mm}$ de diâmetro. A separação de raízes finas de outros materiais orgânicos (fragmentos de serapilheira, insetos, carvão, etc.) é de forma geral uma necessidade, uma vez que influem na variação amostral dos parâmetros radiculares (Moir \& Bachelard, 1969). Portanto, a catação manual das raízes pode ser uma operação imprescindivel, dependendo das condições do material e objetivo de estudo.

\subsection{Avaliação dos principais parâmetros radiculares}

\section{Comprimento de raizes finas}

O comprimento radicular é um dos melhores parâmetros para se estimar a absorção de água e nutrientes (Tennant, 1975; Böhm, 1979; Carbon et al., 1980 e Gonçalves, 1994). A grande dificuldade de se determinar o comprimento radicular deve-se ao fato de muitas vezes ocorrer grande quantidade de raízes num pequeno volume de solo. $O$ comprimento de raízes finas pode ser estimado a partir de sua massa, uma vez que existe uma boa correlação entre eles. Nambiar (1983) observou uma alta correlação entre as 
variáveis massa e comprimento de raizes menores que $1 \mathrm{~mm}$ de diâmetro, independentemente da idade. Devido ao considerável trabalho e, com isso, a limitação do número de amostras na determinação do comprimento de raizes pela sua medição direta, a avaliação do crescimento radicular era viável somente pelo peso. Newman (1966), desenvolveu uma técnica para estimar o comprimento radicular, a qual é baseada na intersecção de pontos sobre uma linha. O procedimento é baseado na relação matemática entre o comprimento de segmentos de raízes e o número de intersecções entre raízes e linhas retas orientadas randomicamente. O método já foi intensivamente utilizado em estudos de raízes finas (Roberts, 1976; Ford \& Deans, 1977; Rowse \& Phillips, 1974; Reicovsky et al., 1970). Mais tarde, essa relação foi adaptada por Marsh (1971) e Tennant (1975), que passaram a utilizar uma grade. A seguir, sistemas automatizados para contagem da intersecção de raízes numa grade foram desenvolvidos, na tentativa de viabilizar os estudos de raízes (Rowse \& Phillips, 1974); contudo, o alto custo e a complexidade limitaram seu uso e difusão. O método adaptado por Tennant (1975) é considerado o método padrão para estudo do comprimento radicular, o qual é o fundamento para seu aperfeiçoamento na atualidade (Bragg et al., 1983; Adams et al., 1989; Jorge et al., 1993; Crestana et al., 1994, Neave \& Florence, 1994).

Jorge et al. (1993) demonstraram a viabilidade do SIARCS (Sistema Integrado para Análises de Raizes e Cobertura do Solo), baseado no processamento e análise de imagens digitais, ao compará-lo com a técnica de intersecção manual apresentada por Tennant (1975). O comprimento radicular calculado através deste sistema mostrou-se mais preciso e rápido que aquele calculado pela técnica convencional de Tennant (1975). Com a intensificação do uso dos "scanners" de mesa e, associado ao SIARCS, os estudos de raízes finas podem se tornar mais frequentes. 


\section{Área de Superficie radicular}

Outro parâmetro importante a destacar refere-se à superfície radicular, representando a melhor relação com o potencial de absorção, assim como a área foliar é a medida mais direta do potencial fotossintético, quando comparada à massa foliar. Berish \& Ewel (1988) obtiveram a superfície radicular a partir do comprimento de raízes finas, considerando que todas as raízes tinham um formato cilíndrico e seu diâmetro igual a metade de sua classe de diâmetro. Como o número de raízes de absorção é muito maior que as demais classes de diâmetro, estabelece-se uma grande interação na interface solo-raíz, já que possuem maior superfície específica.

\section{Biomassa de raizes finas}

A biomassa de raizes finas é muito utilizada para estimar sua composição química, as quais são secas em estufa a $60-70^{\circ} \mathrm{C}$ e a seguir pesadas. Devido a facilidade de obtenção dos dados, seu uso é generalizado e, em muitas ocasiões, complementam as informações obtidas através de outros parâmetros radiculares. 


\section{MATERIAL E MÉTODOS}

\subsection{Caracterização das áreas experimentais}

No presente estudo foram usadas duas áreas experimentais.

Área 1 - Localiza-se numa área de plantio comercial de Eucalyptus grandis Hill Ex Maiden (Coff's Harbour) pertencente à Cia. SUZANO PAPEL E CELULOSE, da Fazenda Entre-Rios, município de Itatinga (SP). As coordenadas geográficas do local são: 23000' de latitude sul, 4852' de longitude oeste e altitude de $750 \mathrm{~m}$. Por ocasião do início dos estudos o povoamento florestal estava com 7 anos de idade. $O$ clima da região é do tipo Cwa, segundo a classificação de KÖEPPEN, ou seja, mesotérmico de inverno seco, em que a temperatura média do mês mais frio (julho) é inferior a $18^{\circ} \mathrm{C}$, e a do mês mais quente (janeiro), superior a $22^{\circ} \mathrm{C}$. O total de chuvas no mês mais seco não ultrapassa $30 \mathrm{~mm}$. Na Figura 1 é apresentado o balanço hídrico desta área. $O$ tipo de solo ocorrente na área é caracterizado como um latossolo vermelho-amarelo, textura argilosa, distrófico, relevo plano a suave ondulado. As características físicas e químicas do solo são apresentadas nas Tabelas $1 \mathrm{e}$ 2.

Área 2 - Localiza-se numa área de plantio comercial de eucaliptos pertencente à Cia. CHAMPION PAPEL E CELULOSE Ltda., do Horto Florestal Nossa Senhora Aparecida, município de Moji Guaçu (SP). As coordenadas geográficas do local são: 2203' de latitude sul, 4659' de longitude oeste e altitude de $650 \mathrm{~m}$. O clima da região é do tipo Cwa. Na Figura 2 é apresentado o balanço hídrico desta área. O tipo de solo ocorrente na área 


\section{Balanço hídrico}

\section{Fazenda Entre-Rios}

\section{Itatinga - SP}

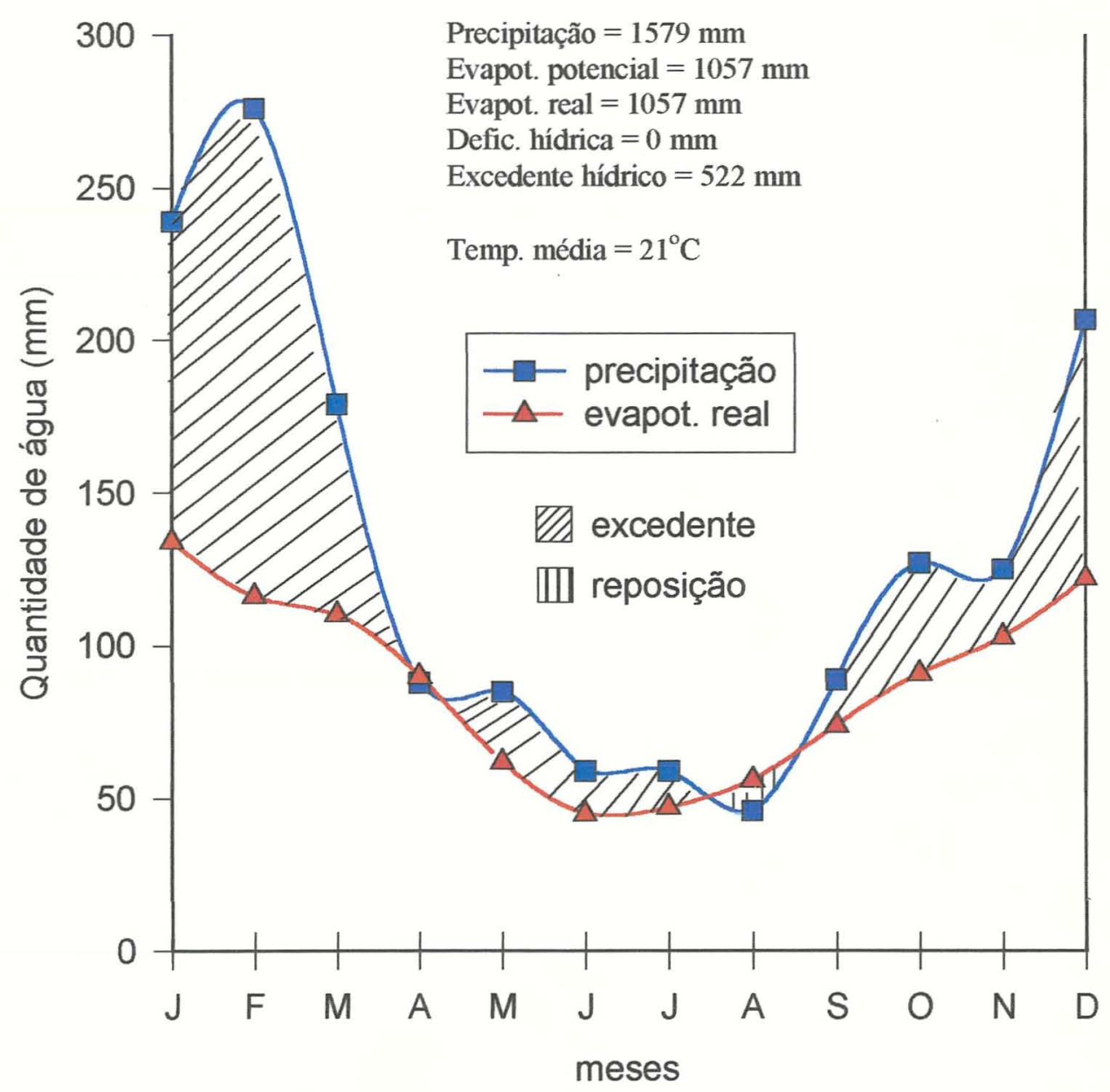

Figura 1. Balanço hídrico segundo Thorntwaite \& Mather (1955) para Fazenda Entre-Rios, admitindo-se $125 \mathrm{~mm}$ de capacidade armazenamento de água no solo. 


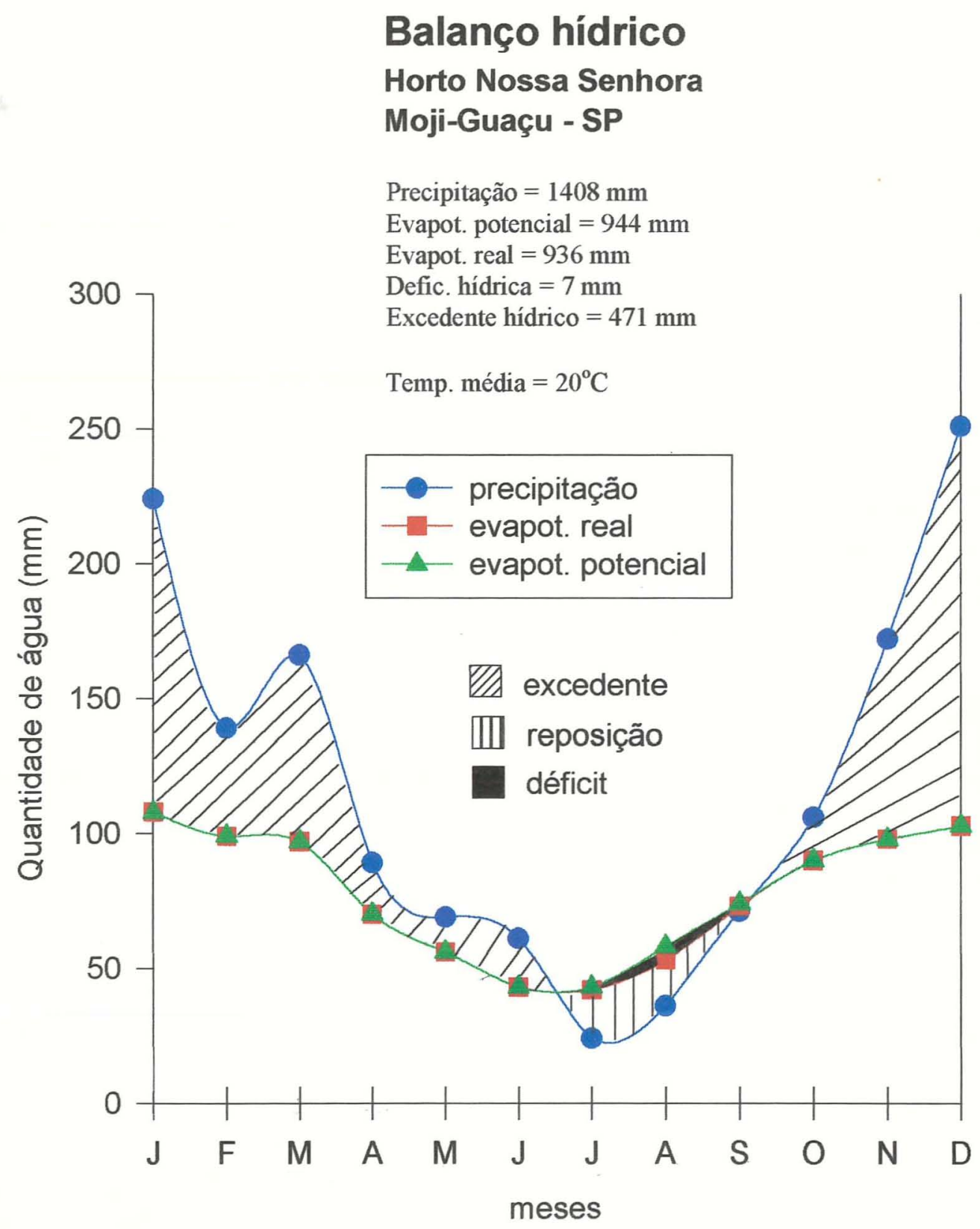

Figura 2. Balanço hídrico segundo Thorntwaite \& Mather (1955) para o Horto Nossa Senhora, admitindo-se $125 \mathrm{~mm}$ de capacidade de armazenamento de água no solo. 
é caracterizado como um latossolo vermelho-amarelo, textura argilosa, distrófico, relevo suave ondulado. As características físicas e químicas do solo são apresentadas nas Tabelas 1 e 2 . O cerrado é a vegetação natural da região. Nesta área foram escolhidos povoamentos de três genótipos distintos: um clone superior, obtido a partir do hibrido Eucalyptus urograndis (Eucalyptus grandis vs. E. urophylla), um clone inferior, obtido a partir do $E$. grandis (Coff's Harbour) e um povoamento de E. grandis (Coff's Harbour) propagado por sementes, todos com 4,5 anos. Os clones foram propagados por enraizamento de estacas.

As condições edafoclimáticas e floristicas das duas áreas são representativas de extensos blocos de florestas homogêneas plantadas com eucalipto no planalto paulista.

$\mathrm{Na}$ área 1 , foram instaladas 4 parcelas experimentais contendo 121 árvores, ou seja, 11 linhas com 11 árvores cada (espaçamento $3,0 \times 1,8 \mathrm{~m}$ ). Cada parcela ocupava uma área de $653 \mathrm{~m}^{2}$. Na área 2, foram instaladas 3 parcelas experimentais de $600 \mathrm{~m}^{2}$ contendo 100 árvores, ou seja, 10 linhas com 10 árvores cada (espaçamento $3,0 \times 2,0 \mathrm{~m}$ ). Cada parcela continha um dos três materiais genéticos pesquisados. Em todas parcelas foram realizadas avaliações do crescimento das árvores, para os seguintes parâmetros: altura, crescimento em diâmetro à altura do peito (d.a.p.), volume sólido de madeira, área basal e índice de sítio.

Para se estimar a produção de biomassa e a absorção de nutrientes, foram definidas 5 classes de diâmetro e posterior abate de uma árvore de cada classe. Para as estimativas de peso seco e composição química dos diferentes componentes das árvores, as folhas, os galhos e os troncos foram separados e pesados após o corte. A estimativa do peso seco dos componentes das árvores foi feito através de amostragens. Cerca de $200 \mathrm{~g}$ 
Tabela 1. Características físicas dos solos da área 1 (Itatinga - S.P.) e 2 (Moji Guaçu - S.P.), sob os povoamentos florestais estudados 1.

\begin{tabular}{|c|c|c|c|c|c|}
\hline Prof. & Areia & Silte & Argila & $\begin{array}{c}\text { Densidade } \\
\text { aparente }\end{array}$ & $\begin{array}{c}\text { Densidade } \\
\text { real }\end{array}$ \\
\hline $\mathrm{cm}$ & 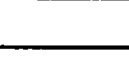 & $\mathrm{g} \mathrm{kg}^{-1}$ & 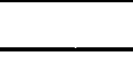 & $-9 c$ & \\
\hline \multicolumn{6}{|c|}{ semente (A1) } \\
\hline $\begin{array}{c}0-10 \\
10-20 \\
20-30 \\
30-50 \\
50-100\end{array}$ & $\begin{array}{l}770 \\
770 \\
760 \\
760 \\
740\end{array}$ & $\begin{array}{l}30 \\
30 \\
20 \\
20 \\
20\end{array}$ & $\begin{array}{l}200 \\
200 \\
220 \\
220 \\
240\end{array}$ & $\begin{array}{l}1,25 \\
1,25 \\
1,30 \\
1,30 \\
1,31\end{array}$ & $\begin{array}{l}2,22 \\
2,22 \\
2,25 \\
2,25 \\
2,25\end{array}$ \\
\hline \multicolumn{6}{|c|}{ clone superior (A2) } \\
\hline $\begin{array}{c}0-10 \\
10-20 \\
20-30 \\
30-50 \\
50-100\end{array}$ & $\begin{array}{l}790 \\
770 \\
760 \\
760 \\
740\end{array}$ & $\begin{array}{l}20 \\
30 \\
20 \\
20 \\
20\end{array}$ & $\begin{array}{l}190 \\
200 \\
220 \\
220 \\
240\end{array}$ & $\begin{array}{l}1,35 \\
1,35 \\
1,35 \\
1,33 \\
1,33\end{array}$ & $\begin{array}{l}2,23 \\
2,23 \\
2,23 \\
2,21 \\
2,21\end{array}$ \\
\hline \multicolumn{6}{|c|}{ clone inferior (A2) } \\
\hline $\begin{array}{c}0-10 \\
10-20 \\
20-30 \\
30-50 \\
50-100\end{array}$ & $\begin{array}{l}780 \\
770 \\
760 \\
740 \\
740\end{array}$ & $\begin{array}{l}20 \\
30 \\
20 \\
30 \\
20\end{array}$ & $\begin{array}{l}200 \\
200 \\
220 \\
230 \\
240\end{array}$ & $\begin{array}{l}1,33 \\
1,33 \\
1,34 \\
1,32 \\
1,30\end{array}$ & $\begin{array}{l}2,21 \\
2,21 \\
2,22 \\
2,21 \\
2,21\end{array}$ \\
\hline \multicolumn{6}{|c|}{ semente (A2) } \\
\hline $\begin{array}{c}0-10 \\
10-20 \\
20-30 \\
30-50 \\
50-100 \\
\end{array}$ & $\begin{array}{l}770 \\
770 \\
760 \\
760 \\
740 \\
\end{array}$ & $\begin{array}{l}20 \\
30 \\
20 \\
20 \\
20\end{array}$ & $\begin{array}{l}210 \\
200 \\
220 \\
220 \\
240 \\
\end{array}$ & $\begin{array}{l}1,33 \\
1,32 \\
1,33 \\
1,32 \\
1,31 \\
\end{array}$ & $\begin{array}{l}2,20 \\
2,20 \\
2,21 \\
2,20 \\
2,21 \\
\end{array}$ \\
\hline
\end{tabular}

${ }^{1} \mathrm{~A} 1$ = área 1 e $\mathrm{A} 2$ = área 2 


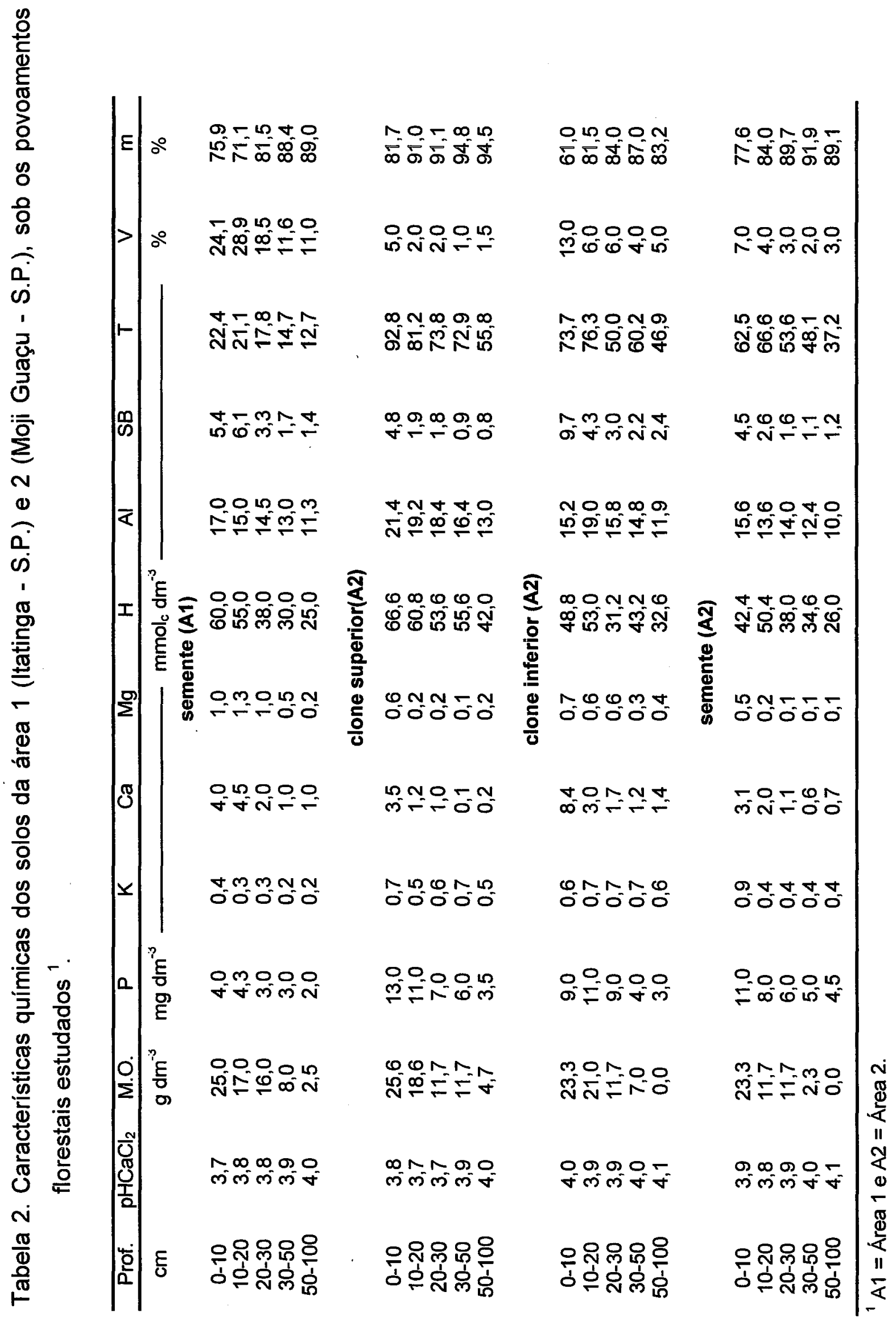


de folhas por árvore, após homogeneização de toda copa, foram amostrados. Os galhos de cada árvore, incluindo a parte do caule com menos de três centímetros de diâmetro, foram agrupados num feixe e da parte intermediária foi obtida uma amostra (cerca de $500 \mathrm{~g}$ ) representativa do conjunto. As amostras de folhas e galhos foram pesadas e, após 72 horas de secagem a $65^{\circ} \mathrm{C}$ (até peso constante), tiveram seus pesos secos e composições químicas determinadas segundo as metodologias propostas por Sarruge \& Haag (1974). Conhecendo-se o peso fresco total dos componentes folhas e galhos, e o peso de material fresco e seco das respectivas amostras, foi possível estimar o peso de material seco total destes componentes para cada árvore abatida.

Com a finalidade de calcular o peso de casca e lenho secos, foram tomados discos com e sem casca das árvores abatidas, em intervalos fixos de 2 metros, da base da árvore até a altura em que o diâmetro era $\leq 3 \mathrm{~cm}$. De posse destas medições, calculou-se os volumes com e sem casca e, pela diferença entre ambos, foi obtido o volume de casca de cada árvore. Para o cálculo dos volumes de madeira com e sem casca foi usada a fórmula de Smallian. Para estimar a quantidade e composição quimica da serapilheira acumulada sobre o solo foram coletadas amostras simples (5 na área 1 e 12 na área 2) por parcela; após serem homogeneizadas, estas deram origem a uma amostra composta. As amostras foram retiradas com um aro de aço circular com $2 \mathrm{~mm}$ de espessura, $5 \mathrm{~cm}$ de altura e $30 \mathrm{~cm}$ de diâmetro. Uma das bordas do aro tem superfície cortante, para facilitar o corte do material depositado nas margens da área amostrada. As amostras foram secas e analisadas quimicamente conforme metodologias utilizadas nas amostras dos componentes das árvores. 


\subsection{Estudos sobre o sistema radicular}

\section{Amostragem de raizes finas e grossas}

Área 1 - Nesta área, foram usadas para a amostragem de raizes finas ( $<3 \mathrm{~mm}$ de espessura), sondas cilindricas de aço inoxidável, com 4,0 e $8,0 \mathrm{~cm}$ de diâmetro e $1,3 \mathrm{~m}$ de comprimento (Figura 3). Foram amostradas as raizes de 4 árvores médias quanto ao diâmetro à altura do peito (d.a.p.), selecionadas, aleatoriamente, no interior de cada uma das parcelas experimentais. Uma escolha cuidadosa das árvores é fundamental para que fatores como a presença de falhas, tocos e plantas daninhas possam ser evitados. Tendo como ponto de partida o tronco das árvores, foram feitas amostragens a intervalos de $50 \mathrm{~cm}$ sobre duas linhas ortogonais e imaginárias, uma localizada sobre a linha de plantio e a outra perpendicular a esta. Foram locados 3 pontos de coleta sobre cada linha. A distribuição de raízes finas no perfil de solo foram determinadas tendo por base amostragens feitas nas camadas $0-10,10-20,20-30,30-50,50-100$ e 100-150 cm de profundidade; as raizes entremeadas na serapilheira foram coletadas separadamente. As amostragens foram realizadas em abril de 1995. Na mesma época, para se fazer uma estimativa do peso seco e composição química das raízes grossas (>3 mm de espessura), três árvores médias quanto ao d.a.p. foram removidas, de três parcelas experimentais distintas. Para isso, foram escavadas trincheiras ao redor das árvores, com $5,4 \mathrm{~m}^{2}$. Depois de cuidadosa remoção do solo e exposição das raízes, os sistemas radiculares dessas árvores foram removidos e tiveram seus pesos frescos determinados. No solo removido das trincheiras, foram coletados os fragmentos de raízes. Do material obtido, tirou-se uma amostra com aproximadamente $1 \mathrm{~kg}$, a qual foi seca a $65^{\circ} \mathrm{C}$ até peso constante e usada para as estimativas de peso seco e análise da composição química. 


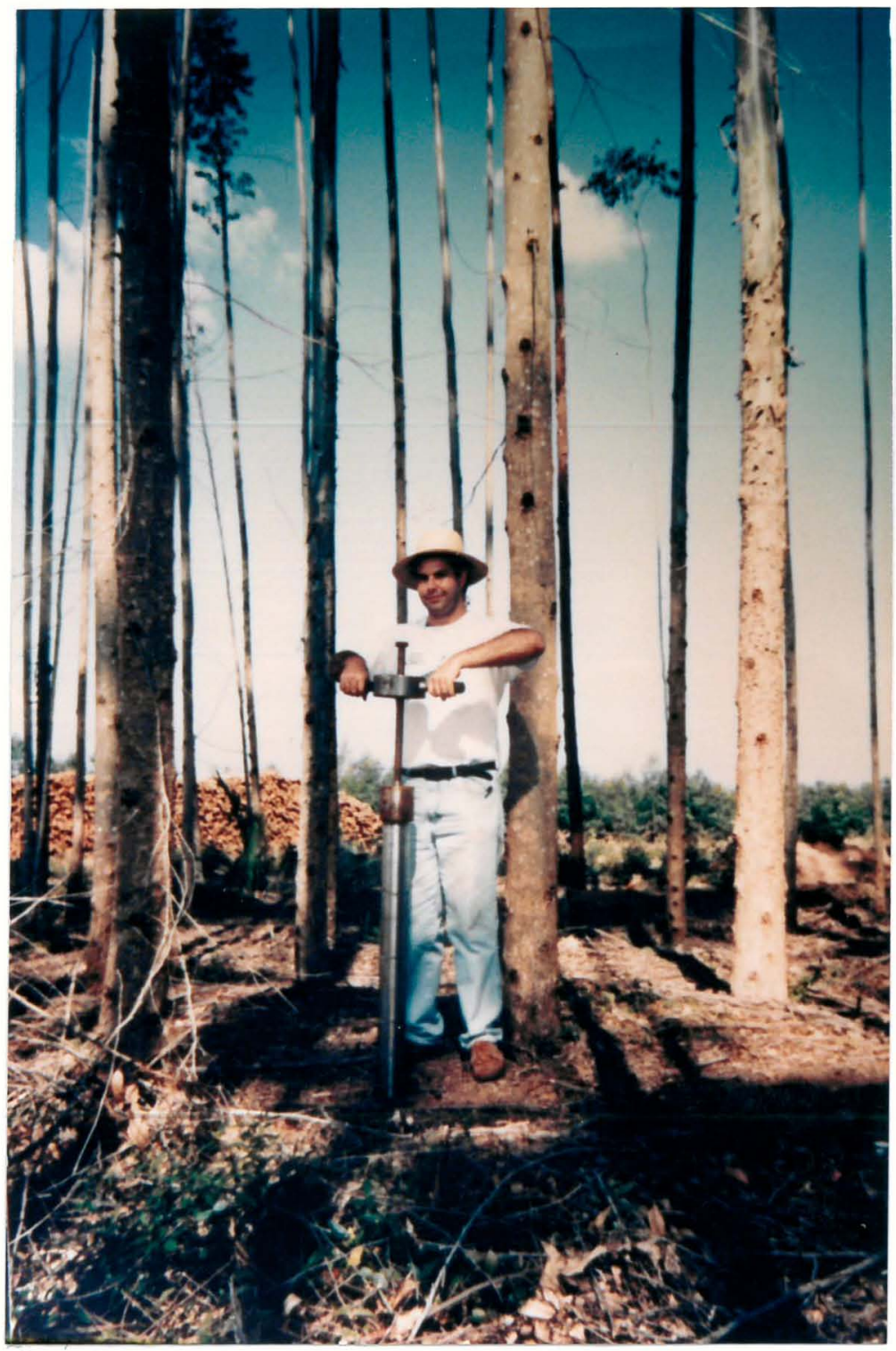

Figura 3. Sonda de $4 \mathrm{~cm}$ de diâmetro usada para amostragem de raízes finas. 
Área 2 - Nesta área, a amostragem de raízes finas foi feita com uma sonda de $4 \mathrm{~cm}$ de diâmetro e com a remoção de monolitos do interior de trincheiras. A partir da comparação das sondas de 4 e $8 \mathrm{~cm}$ de diâmetro realizada na área 1 , optou-se pelo uso da sonda menor pois apresentaram similaridade na precisão. Com relação a sonda, o método de amostragem foi similar ao usado na área 1. Para a remoção de monolitos, no centro de cada parcela experimental, junto a duas árvores de d.a.p. médio, foram abertas trincheiras retangulares, que tinham um dos seus maiores lados alinhados com as linhas de plantio e a largura igual à metade do espaçamento entrelinhas. $O$ comprimento dos lados maiores era equivalente ao espaçamento entre as árvores dentro da linha de plantio e a profundidade igual a 1,8 $\mathrm{m}$. Nas camadas de solo iguais a $0-10,10-20,20-30,30-50,50-100$ e $100-150 \mathrm{~cm}$ foram removidos monolitos com $10 \mathrm{~cm}$ de altura, $10 \mathrm{~cm}$ de largura e $30 \mathrm{~cm}$ de comprimento, de fora a fora na face alinhada com a linha de plantio (Figuras 4 e 5). A extração dos monolitos foi feita com uma forma de aço de bordas cortantes, introduzida nos perfis de solo por meio de marteladas. Os mesmos procedimentos usados na área 1 também foram aplicados aqui para a amostragem das raízes grossas (> $3 \mathrm{~mm}$ ). Todos os três materiais genéticos selecionados nessa área foram amostrados em julho de 1995 e janeiro de 1996.

\section{Separação das Raízes das Amostras de Solo}

As amostras retiradas com as sondas $e$ os monolitos foram acondicionadas em sacos plásticos e levadas para o laboratório. A lavagem das amostras para a remoção das partículas do solo foi realizada sobre um jogo de peneiras com crivos de 2 e $0,5 \mathrm{~mm}$. Devido a natureza arenosa dos solo, não foi necessário o uso de agentes dispersantes. Após a lavagem, as raízes foram acondicionadas numa solução contendo $10 \%$ de álcool etílico. 


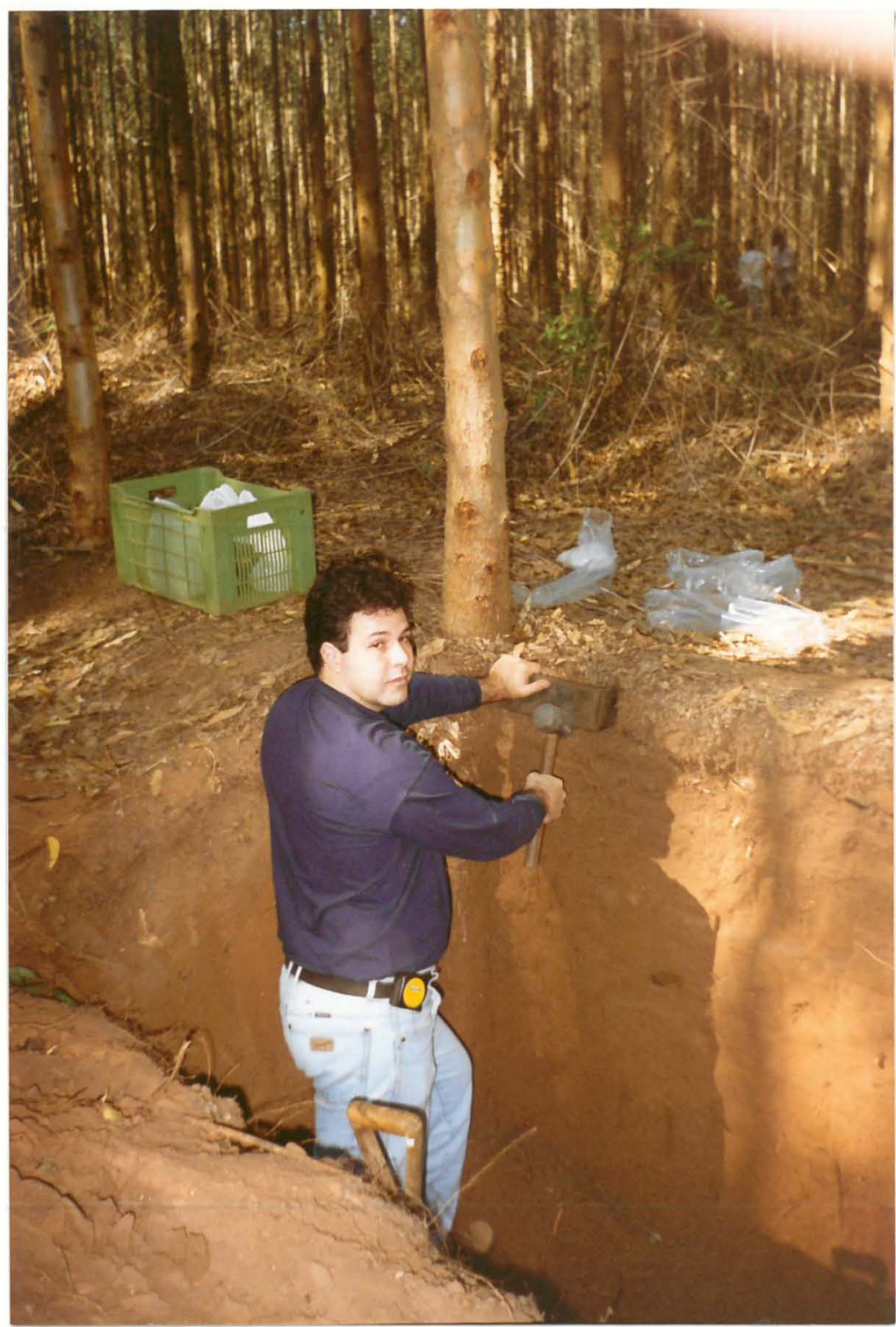

Figura 4. Remoção de monolitos com o uso de uma forma metálica $(10 \times 10 \times 30 \mathrm{~cm})$. 


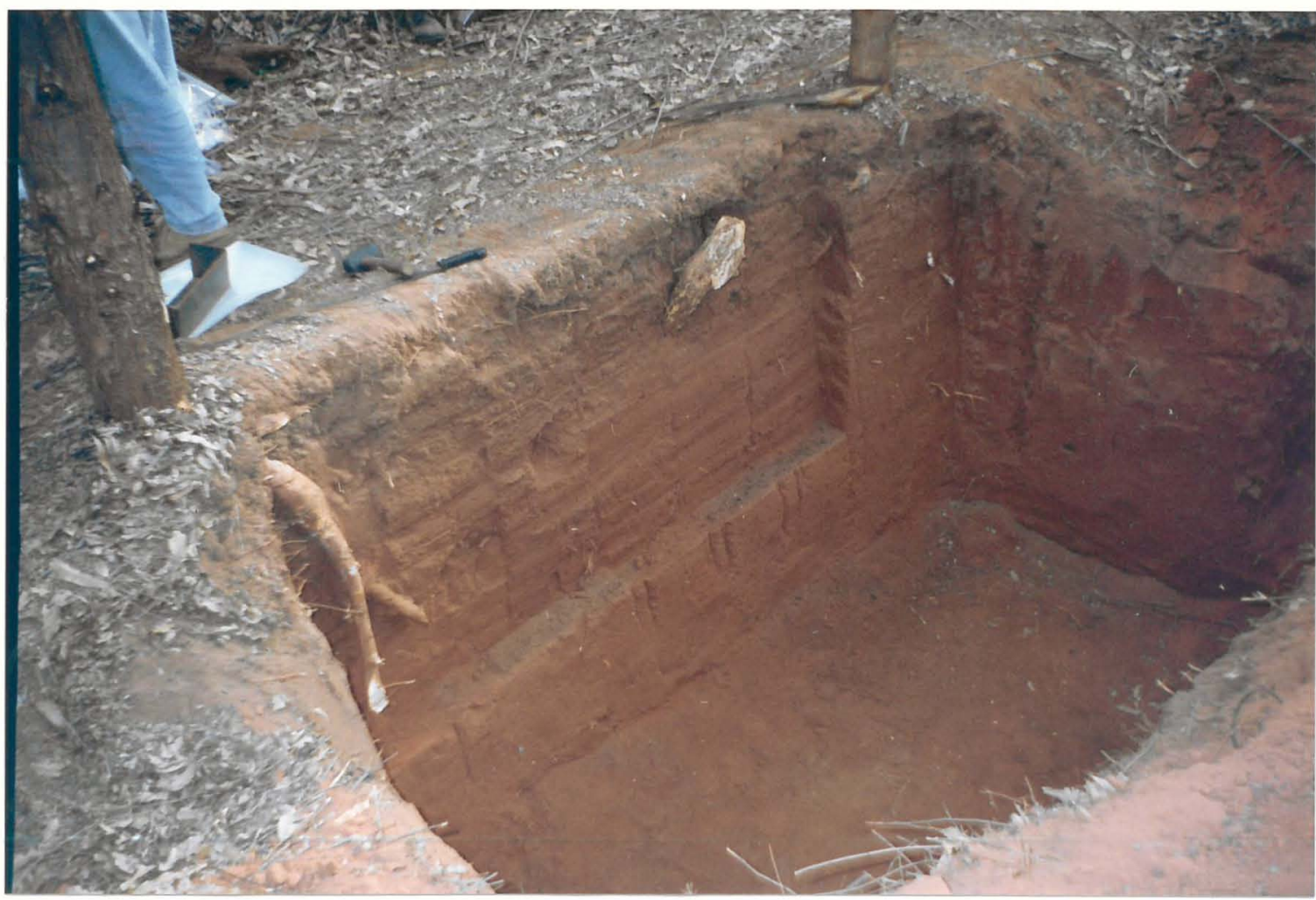

Figura 5. Aspecto da trincheira após a remoção dos monolitos. 
Todo material (solotraíz) não prontamente separado foi mantido sob condições de baixa temperatura $\left(4^{\circ} \mathrm{C}\right)$.

\section{Estimativa do comprimento de raizes finas}

Somente foram consideradas as raízes vivas com diâmetro $\leq 3 \mathrm{~mm}$. Duas classes de raízes foram separadas: a) raízes com diâmetro $>1 \mathrm{~mm}$ e b) raizes com diâmetro $\leq 1 \mathrm{~mm}$. O comprimento radicular foi estimado pelo sistema SIARCS (Sistema Integrado para Análise de Raízes e Cobertura do Solo), desenvolvido pela EMBRAPA/CNPDIA (com o apoio da FAPESP projeto 90/3773-7), conforme metodologia apresentada por Jorge et al. (1993). Inicialmente, as raízes foram secionadas em partes de aproximadamente $5 \mathrm{~cm}$, e distribuídas em uma bandeja de vidro de $15 \times 21 \mathrm{~cm}$ e $1 \mathrm{~cm}$ de altura $(2 \mathrm{~mm}$ de espessura). Sobre estas foi colocado uma lâmina d'água, suficiente para cobrí-las. A bandeja foi colocada sobre um "scanner" de mesa de resolução espacial de $1200 \mathrm{dpi}$, o qual digitalizou as imagens das raízes, transferindo-as automaticamente para um arquivo no computador (Figura 6). A partir desta fase, por meio do sistema SIARCS, as imagens foram binarizadas e esqueletonizadas para o cálculo do comprimento radicular (Figura 7). 


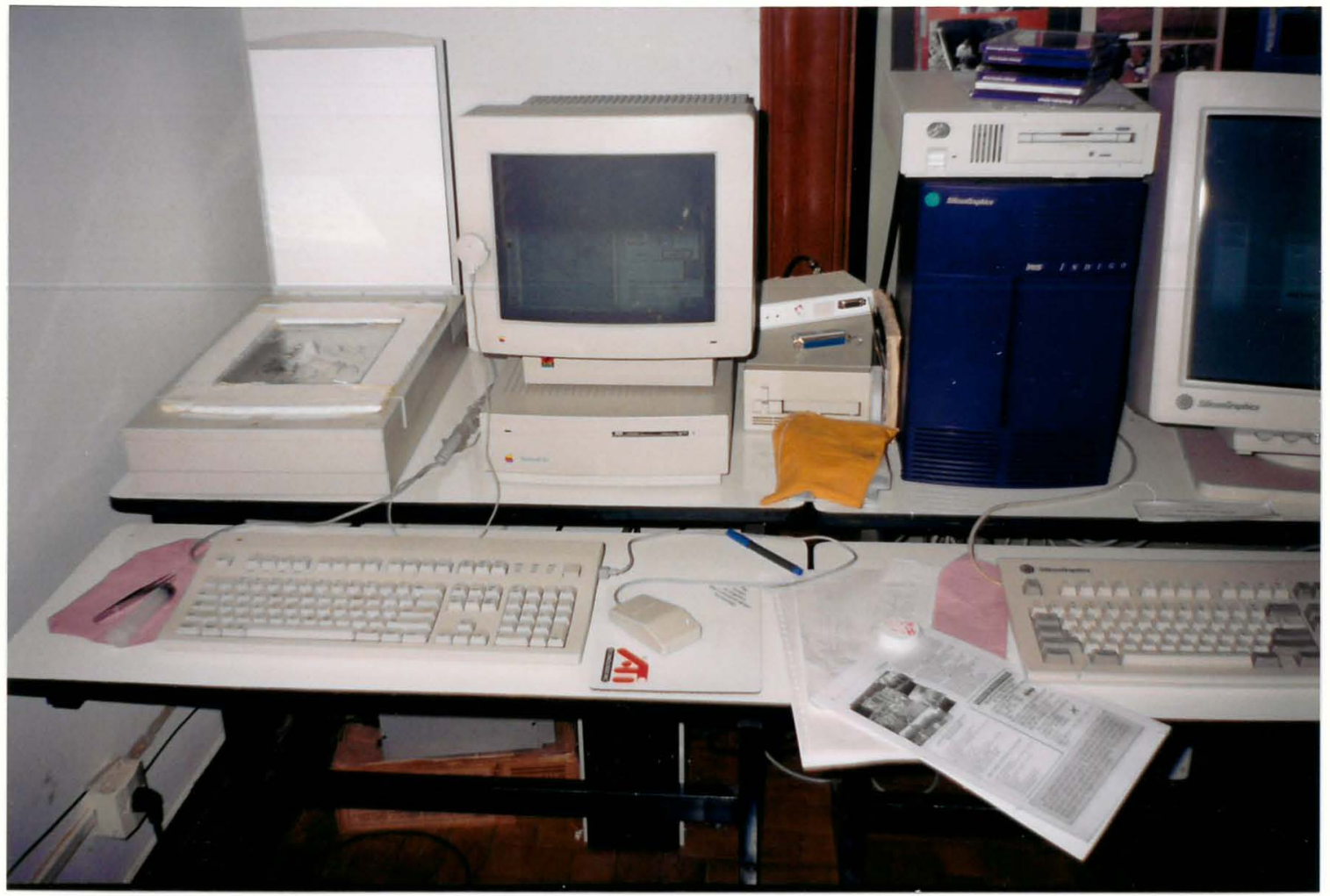

Figura 6. Digitalização de imagens (EMBRAPA./CNPDIA). 
Estimativa do peso seco e composição química das raizes finas

Após a estimativa do comprimento radicular, as amostras de raizes foram submetidas à secagem em estufa a $65^{\circ} \mathrm{C}$, até peso constante. Depois de moídas, as raizes tiveram suas composições químicas determinadas segundo a metodologia proposta por SARRUGE \& HAAG (1974). 


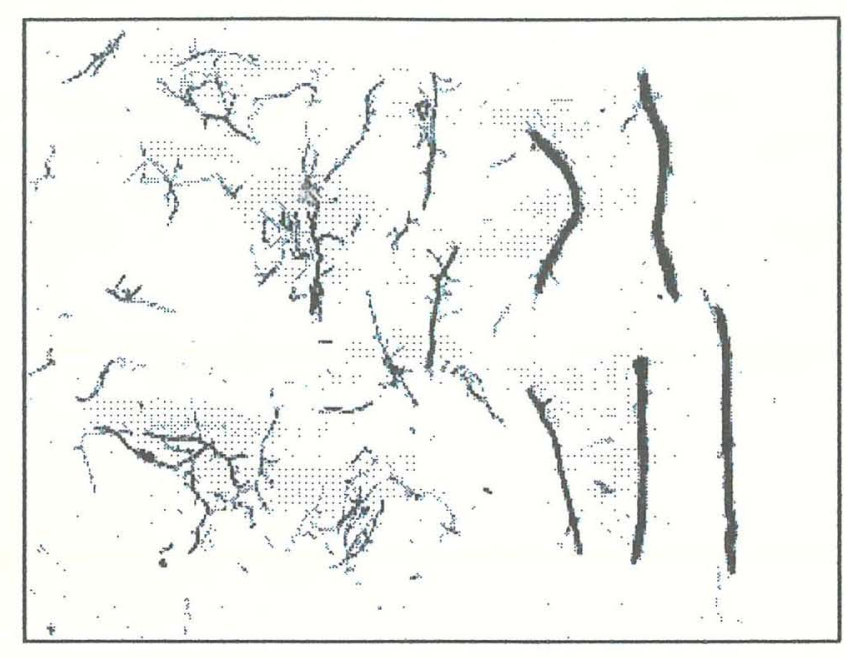

(a)

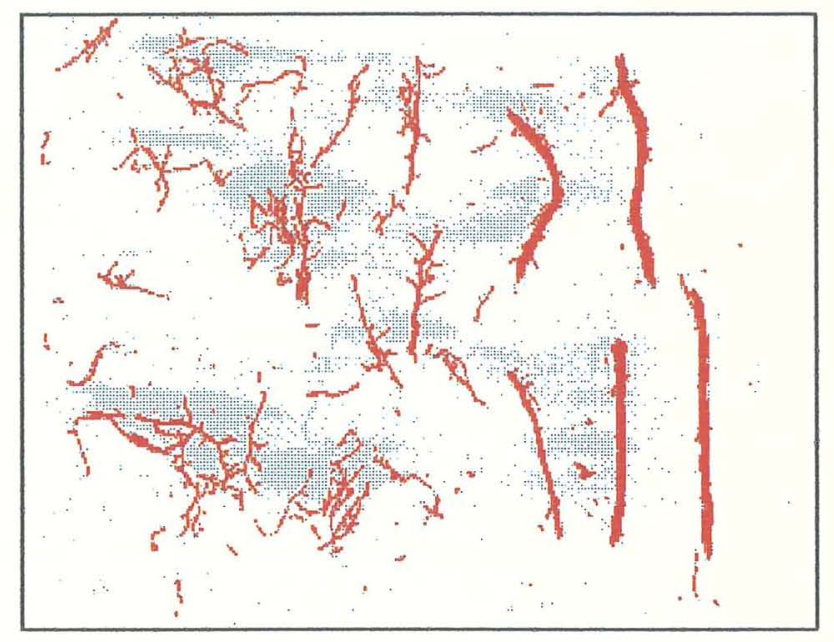

(b)

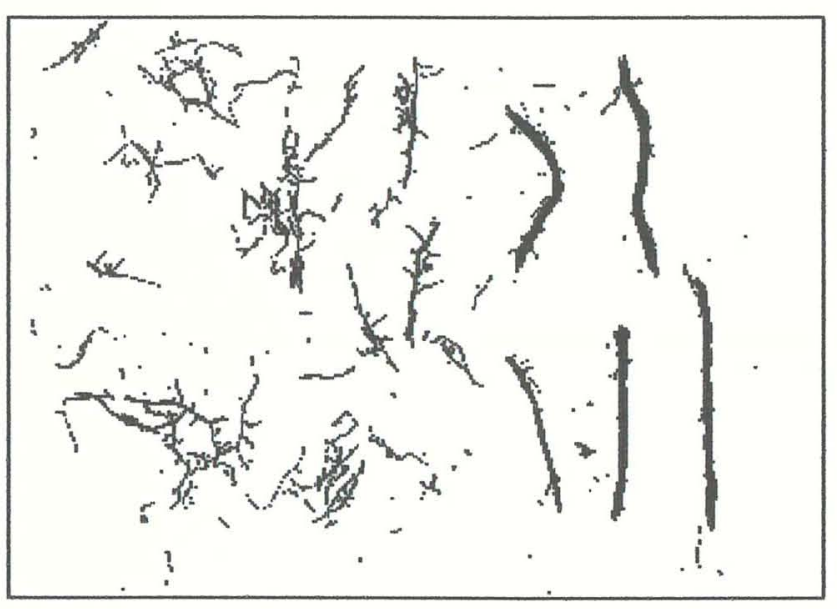

(c)

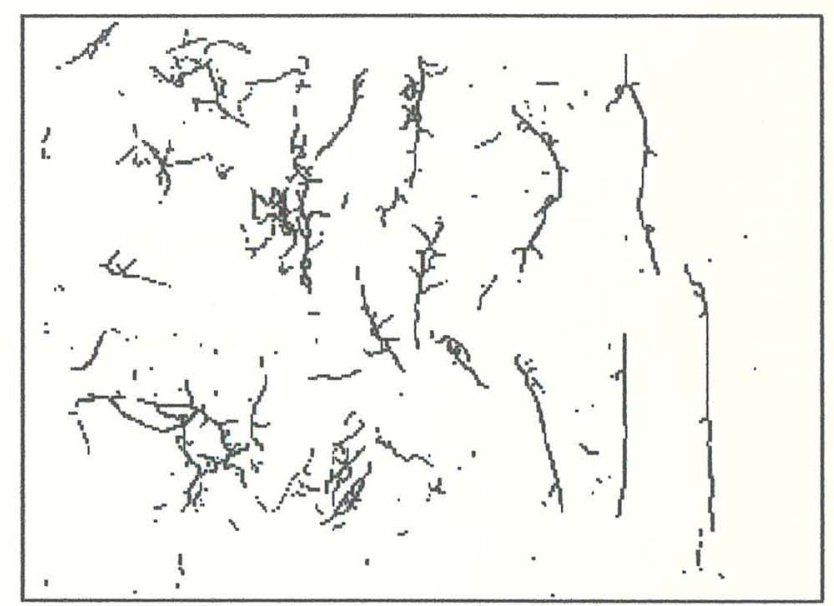

(d)

Figura 7. (a) Imagem digitalizada, com resolução de 100 dpi e 256 tons de cinza no formato bitmap; (b) Imagem submetida ao filtro "treshold" para a marcação das raízes; (c) Imagem binarizada (as raizes ficam setadas na cor preta); e (d) Imagem esqueletonizada, pronta para a contagem dos "pixels". 


\section{RESULTADOS E DISCUSSÃO}

\section{1. Índices de crescimento e biomassa de diversos compartimentos florestais}

Na Tabela 3 são apresentados os índices de crescimento dos diferentes genótipos em estudo. $\mathrm{Na}$ área 2 , a produção volumétrica de madeira do clone superior (hibrido E. grandis $\times$ E. urophylla) foi maior do que a dos demais genótipos. Enquanto este clone produziu $115,9 \mathrm{~m}^{3} \mathrm{ha}^{-1}$ de volume sólido (sem casca), o clone inferior (E. grandis) produziu $98,1 \mathrm{~m}^{3} \mathrm{ha}^{-1}$ e o povoamento propagado por semente (pps) (E. grandis) $91,7 \mathrm{~m}^{3} \mathrm{ha}^{-1}$, aos 4,5 anos de idades. A percentagem de falhas foi também bastante distinta entre os genótipos: 8, 13 e $27 \%$, para o clone superior, clone inferior e pps, respectivamente. $O$ número de árvores dominadas foi também menor nos genótipos mais produtivos.

A biomassa total das árvores foi 168,$7 ; 86,9 ; 79,2$ e $69,7 \mathrm{t} \mathrm{ha}^{-1}$ para o pps (área 1), clone superior, clone inferior e pps (área 2), respectivamente (Tabela 4). A biomassa radicular do clone superior representa $16 \%$ da biomassa total, sendo expressivamente maior para os demais genótipos, cerca de $21,5 \%$. $\mathrm{Na}$ área 2 , a percentagem de raizes finas variou de 2,6 a $6,3 \%$ do peso total de biomassa, para o clone superior e clone inferior respectivamente. Apesar da maior produção de folhas (4 $\left.\mathrm{t} \mathrm{ha}^{-1}\right)$ verificada para o clone mais produtivo, sua biomassa de galhos é praticamente igual ao clone inferior. Conclui-se desses dados que o clone superior apresenta uma maior área foliar (maior atividade fotossintética) com uma alocação relativamente menor de fotoassimilados para a constituição de galhos mais espessos $e$ raízes. 


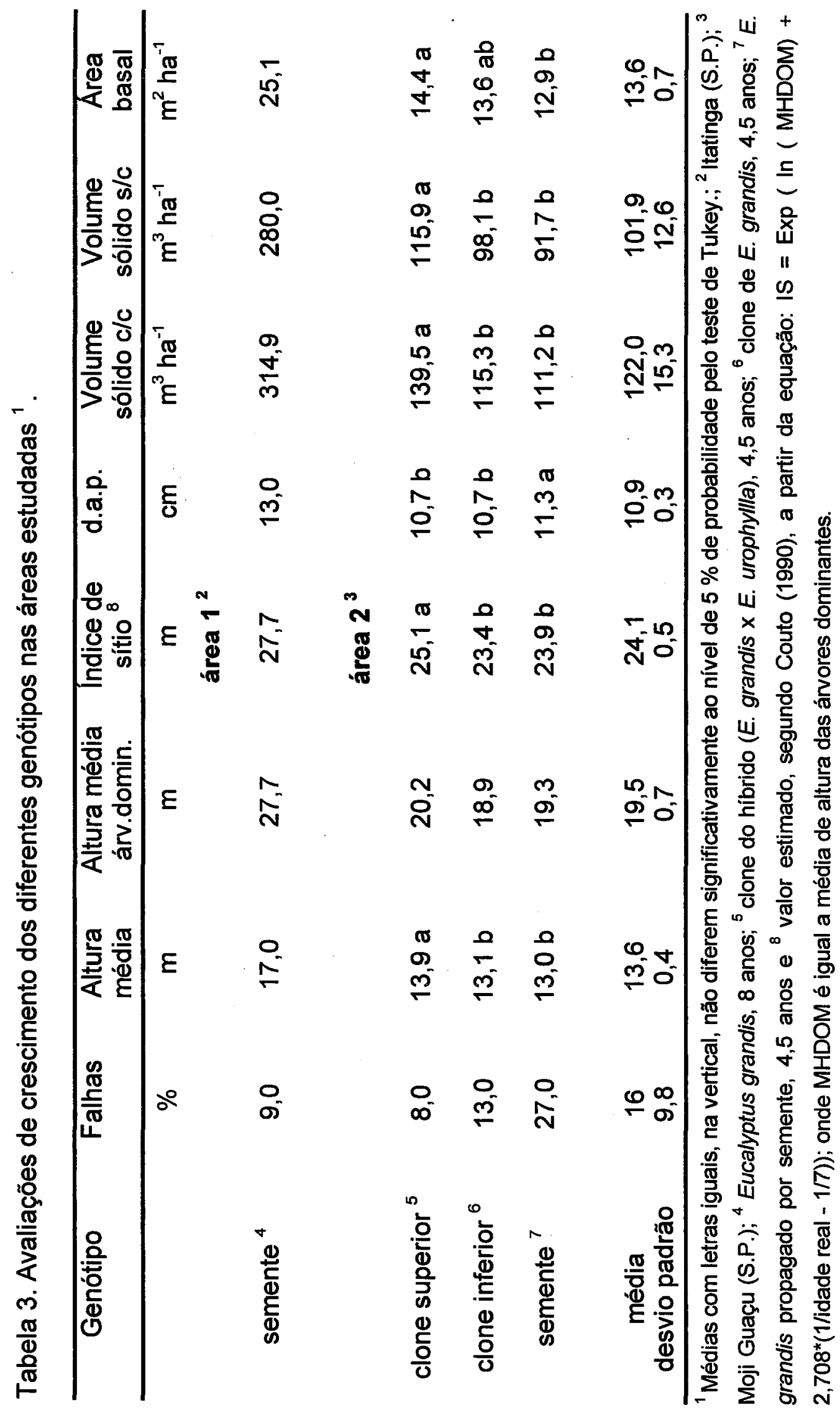




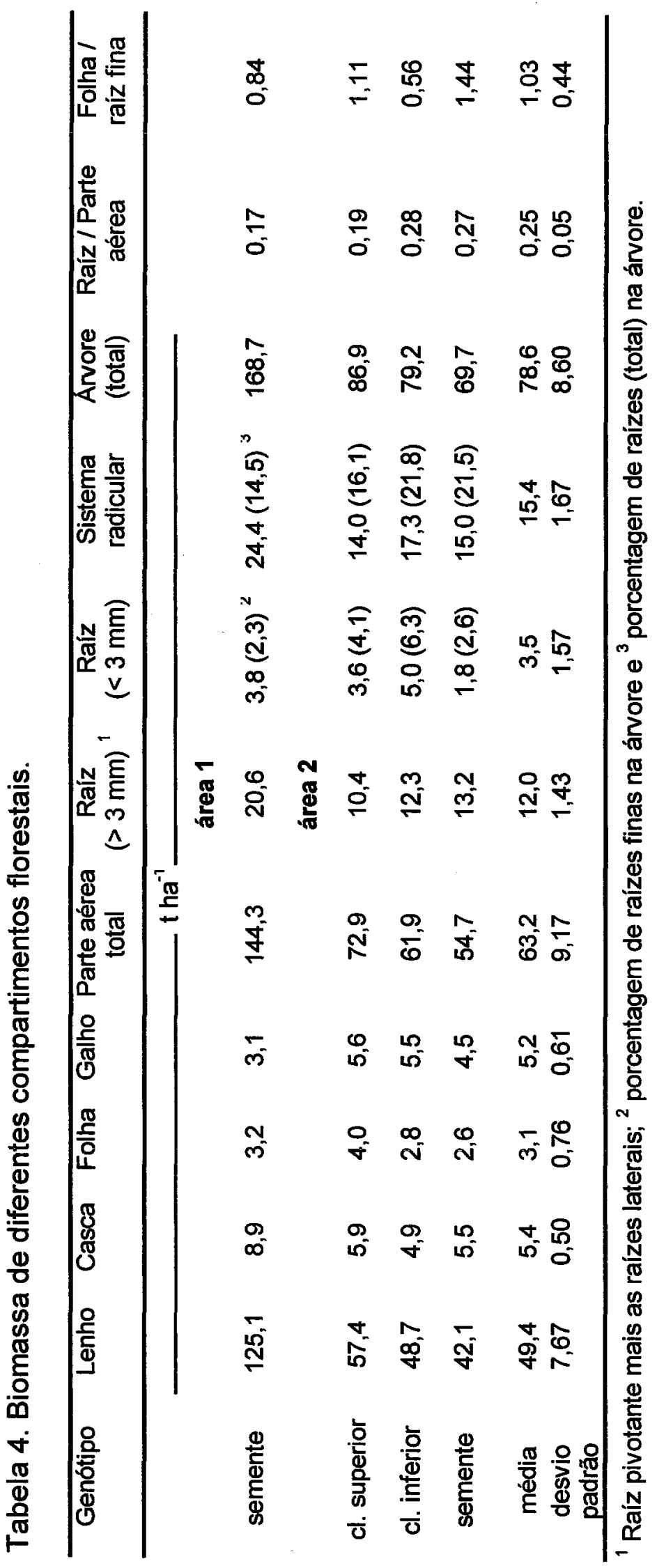


Observou-se também a formação de copas mais abertas e galhos mais espessos nos povoamentos ocupados pelo clone inferior e pps, ambos com alta porcentagem de falhas.

A relação folhas/raízes finas (peso/peso) fornece uma indicação aproximada da relação fonte/dreno de fotoassimilados para os diferentes genótipos (Tabela 4). A maior relação foi observada para 0 povoamento do clone inferior $(0,56)$, evidenciando sua menor eficiência de uso dos fotoassimilados relativamente ao clone superior $(1,11)$. Em outras palavras, proporcionalmente, a quantidade de fotoassimilados alocados no compartimento raízes finas é maior nos genótipos menos produtivos. Quando se compara sítios florestais com diferentes potenciais produtivos, essas constataçōes podem estar associadas às disponibilidades de água e nutrientes do solo (Reis et al, 1985 e Gonçalves, 1994). Ou seja, as árvores ampliam seu sistema radicular para aumentar a capacidade de absorção de água e nutrientes nos solos menos férteis. No presente estudo, as relações folhas/raízes finas e a distribuição de raízes finas no perfil de solo estão associadas com a capacidade de adaptação dos diferentes genótipos aos estresses ambientais, como será discutido posteriormente.

A biomassa de serapilheira acumulada foi de $23,7 \mathrm{t} \mathrm{ha}^{-1}$ no pps (área 1) e 9,2; 19,8 e 10,5 t ha ${ }^{-1}$ nos clones superior, inferior e pps (área 2), respectivamente; isto corresponde a 10,20 e $13 \%$ da biomassa total, dos referidos povoamentos (área 2). No clone inferior, a maior quantidade de serapilheira se deve, provavelmente, à maior queda de folhas decorrente da menor adaptabilidade deste genótipo às condições ambientais adversas presentes no local. 


\subsection{Composição química e estoque de nutrientes em diversos compartimentos florestais}

As Tabelas 5 e 6 apresentam a composição química e o estoque de nutrientes nos diversos compartimentos florestais dos genótipos estudados. Em função da maior idade e biomassa acumulada, nos compartimentos do pps (área 1) foram encontradas as maiores quantidades de nutrientes absorvidos e acumulados.

$\mathrm{Na}$ área 2, os clones acumularam maiores quantidades de $\mathrm{N}$, $\mathrm{P}, \mathrm{K}$ e Ca na biomassa viva e menores quantidades de $\mathrm{Mg}$ do que o pps (Tabela 6). A despeito das maiores quantidades acumuladas, os clones produziram mais unidades de peso de biomassa por unidade de peso de $N, P$, $\mathrm{K}$ e $\mathrm{Mg}$ estocadas (maior eficiência de uso desses nutrientes) do que o pps (Tabela 7). $O$ clone superior foi muito mais eficiente do que o pps no uso de $P$, $\mathrm{K}$ e Mg. Por outro lado, este clone foi muito menos eficiente no uso de $\mathrm{Ca}$ relativamente ao pps. Esta grande demanda de $\mathrm{Ca}$ dos clones pode ser confirmada pelo $\mathrm{pH}$ mais baixo no solo sob estes povoamentos. Isto tem grandes implicações para os programas de fertilizações minerais. Em virtude das baixas concentrações e reservas de Ca na maioria dos solos usados para fins de reflorestamentos, as fertilizações devem prever, necessariamente, a aplicação de consideráveis quantidades de $\mathrm{Ca}$, junto com as fontes de $\mathrm{N}, \mathrm{P}$ e K ou por meio da calagem. 
Tabela 5. Composição química dos diferentes compartimentos das árvores ${ }^{1}$.

\begin{tabular}{|c|c|c|c|c|c|}
\hline Compartimento & $\mathbf{N}$ & $\mathrm{P}$ & $\bar{K}$ & $\mathrm{Ca}$ & $\mathrm{Mg}$ \\
\hline & \multicolumn{5}{|c|}{$-\mathrm{gkg}^{-1}$} \\
\hline & \multicolumn{5}{|c|}{ semente (A1) } \\
\hline raíz (> 3mm) & 3,65 & 0,13 & 1,37 & 1,02 & 0,31 \\
\hline raíz $(<3 \mathrm{~mm})$ & 7,06 & 0,37 & 0,36 & 3,89 & 1,07 \\
\hline lenho & 1,79 & 0,15 & 0,85 & 0,88 & 0,13 \\
\hline casca & 4,01 & 1,33 & 5,33 & 10,67 & 1,67 \\
\hline galho & 0,50 & 0,08 & 0,26 & 0,57 & 0,10 \\
\hline folha & 17,92 & 1,59 & 6,53 & 7,80 & 2,70 \\
\hline \multirow[t]{2}{*}{ serapilheira } & 7,90 & 0,40 & 1,40 & 8,80 & 1,00 \\
\hline & \multicolumn{5}{|c|}{ clone superior (A2) } \\
\hline raíz (> $3 \mathrm{~mm})$ & 3,01 & 0,11 & 1,40 & 12,60 & 0,90 \\
\hline raíz (< 3 mm) & 6,18 & 0,38 & 0,27 & 4,77 & 0,90 \\
\hline lenho & 1,54 & 0,11 & 0,90 & 7,20 & 0,60 \\
\hline casca & 3,01 & 0,57 & 2,30 & 18,80 & 1,20 \\
\hline galho & 3,50 & 0,34 & 2,20 & 1,80 & 0,15 \\
\hline folha & 18,06 & 1,59 & 5,60 & 5,40 & 1,20 \\
\hline \multirow[t]{2}{*}{ serapilheira } & 8,75 & 0,46 & 0,70 & 14,60 & 1,00 \\
\hline & \multicolumn{5}{|c|}{ clone inferior (A2) } \\
\hline raiz (> $3 \mathrm{~mm})$ & 2,38 & 0,11 & 1,00 & 3,90 & 0,90 \\
\hline raíz $(<3 \mathrm{~mm})$ & 5,66 & 0,45 & 0,17 & 3,82 & 0,90 \\
\hline lenho & 1,96 & 0,11 & 0,90 & 7,40 & 0,60 \\
\hline casca & 4,20 & 0,46 & 2,20 & 21,40 & 2,00 \\
\hline galho & 4,83 & 0,91 & 3,10 & 2,70 & 0,15 \\
\hline folha & 17,92 & 1,48 & 6,80 & 7,10 & 1,20 \\
\hline \multirow[t]{2}{*}{ serapilheira } & 8,75 & 0,57 & 0,60 & 14,80 & 0,80 \\
\hline & \multicolumn{5}{|c|}{ semente (A2) } \\
\hline raízes (> $3 \mathrm{~mm}$ ) & 3,01 & 0,17 & 1,20 & 7,00 & 0,60 \\
\hline raízes $(<3 \mathrm{~mm})$ & 7,98 & 0,60 & 0,09 & 5,60 & 0,68 \\
\hline lenho & 1,75 & 0,17 & 1,10 & 5,20 & 1,80 \\
\hline casca & 3,15 & 0,46 & 3,10 & 14,20 & 1,00 \\
\hline galho & 3,50 & 0,68 & 1,90 & 1,75 & 0,15 \\
\hline folha & 20,16 & 1,25 & 5,80 & 5,40 & 0,90 \\
\hline serapilheira & - & - & - & - & - \\
\hline
\end{tabular}

${ }^{1} \mathrm{~A} 1$ = área 1 e A2 = área 2. 
Tabela 6. Conteúdo de nutrientes em diversos compartimentos dos povoamentos florestais ${ }^{1}$.

\begin{tabular}{|c|c|c|c|c|c|c|}
\hline Compartimento & Biomassa & $\mathbf{N}$ & $P$ & $K$ & $\mathrm{Ca}$ & $\mathrm{Mg}$ \\
\hline & - $\mathrm{tha}^{-1}$ & \multicolumn{5}{|c|}{$-\mathrm{kg} \mathrm{ha}^{-1}$} \\
\hline & & \multicolumn{5}{|c|}{ semente (A1) } \\
\hline raíz (> 3mm) & 20,6 & 75,3 & 2,7 & 28,2 & 20,9 & 6,4 \\
\hline raiz (<3mm) & 3,6 & 22,4 & 1,2 & 1,0 & 11,9 & 3,1 \\
\hline lenho & 125,1 & 224,3 & 18,8 & 106,8 & 110,5 & 16,3 \\
\hline casca & 8,9 & 35,7 & 11,8 & 47,5 & 94,9 & 14,8 \\
\hline galho & 3,1 & 15,4 & 2,4 & 8,0 & 17,6 & 3,1 \\
\hline folha & 3,2 & 57,3 & 5,1 & 20,9 & 25,0 & 8,6 \\
\hline serapilheira & 23,7 & 187,2 & 9,5 & 35,5 & 208,6 & 23,7 \\
\hline \multicolumn{3}{|c|}{. } & \multicolumn{4}{|c|}{ clone superior (A2) } \\
\hline raíz (> 3mm) & 10,4 & 31,3 & 1,1 & 14,6 & 131,0 & 9,4 \\
\hline raíz $(<3 \mathrm{~mm})$ & 3,6 & 20,9 & 1,3 & 1,0 & 15,7 & 3,0 \\
\hline lenho & 57,4 & 88,4 & 6,3 & 51,7 & 413,3 & 34,4 \\
\hline casca & 5,9 & 17,8 & 3,4 & 13,6 & 110,9 & 7,1 \\
\hline galho & 5,6 & 19,6 & 1,9 & 12,3 & 10,1 & 0,8 \\
\hline folha & 4,0 & 72,1 & 6,3 & 22,3 & 21,5 & 4,8 \\
\hline \multirow[t]{2}{*}{ serapilheira } & 9,2 & 80,5 & 4,2 & 6,4 & 134,3 & 9,2 \\
\hline & & & \multicolumn{4}{|c|}{ clone inferior (A2) } \\
\hline raíz (> 3mm) & 12,3 & 29,3 & 1,4 & 12,3 & 48,0 & 11,1 \\
\hline raíz (<3mm) & 4,9 & 28,5 & 1,7 & 0,7 & 15,5 & 3,8 \\
\hline lenho & 48,7 & 95,5 & 5,4 & 43,8 & 360,4 & 29,2 \\
\hline casca & 4,9 & 20,6 & 2,3 & 10,8 & 104,9 & 9,8 \\
\hline galho & 5,5 & 26,6 & 5,0 & 17,1 & 14,9 & 0,8 \\
\hline folha & 2,8 & 50,7 & 4,2 & 19,2 & 20,1 & 3,4 \\
\hline \multirow[t]{2}{*}{ serapilheira } & 19,7 & 206,0 & 11,3 & 11,9 & 292,3 & 15,8 \\
\hline & & \multicolumn{5}{|c|}{ semente (A2) } \\
\hline raíz (> 3mm) & 13,2 & 39,7 & 2,2 & 15,8 & 92,4 & 7,9 \\
\hline raíz (<3mm) & 1,8 & 13,0 & 0,91 & 0,13 & 8,38 & 1,0 \\
\hline lenho & 42,1 & 73,7 & 7,2 & 46,3 & 218,9 & 75,8 \\
\hline casca & 5,5 & 17,3 & 2,5 & 17,1 & 78,1 & 5,5 \\
\hline galho & 4,5 & 15,8 & 3,1 & 8,6 & 7,9 & 0,7 \\
\hline folha & 2,6 & 52,4 & 3,3 & 15,1 & 14,0 & 2,3 \\
\hline serapilheira & 10,5 & - & - & - & - & $\underline{-}$ \\
\hline
\end{tabular}

${ }^{1} \mathrm{~A} 1$ = área 1 e A2 = área 2. 
Tabela 7. Eficiência de uso dos nutrientes ${ }^{1}$ na biomassa viva acumulada para os diferentes genótipos.

\begin{tabular}{lccccc}
\hline \multirow{2}{*}{ Genótipo } & \multicolumn{5}{c}{ Eficiência de uso } \\
\cline { 2 - 6 } & $\mathrm{N}$ & $\mathrm{P}$ & $\mathrm{K}$ & $\mathrm{Ca}$ & $\mathrm{Mg}$ \\
\hline semente (E. grandis), área 1 & 380 & 3910 & 770 & 590 & 3140 \\
clone superior, área 2 & 350 & 4280 & 750 & 120 & 1460 \\
clone inferior, área 2 & 310 & 3950 & 760 & 140 & 1360 \\
semente, área 2 & 330 & 3630 & 680 & 170 & 750 \\
\hline
\end{tabular}

${ }^{1}$ Eficiência de uso dos nutrientes $=\left(\right.$ quantidade de biomassa viva acumulada, $\left.\mathrm{kg} \mathrm{ha}^{-1}\right) \div$ (quantidade de nutriente acumulada na biomassa viva, $\mathrm{kg} \mathrm{ha}^{-1}$ ).

Tabela 8. Eficiência de uso dos nutrientes ${ }^{1}$ na serapilheira para os diferentes genótipos.

\begin{tabular}{lccccc}
\hline \multirow{2}{*}{ Genótipo } & \multicolumn{5}{c}{ Eficiência de uso } \\
\cline { 2 - 6 } & $\mathrm{N}$ & $\mathrm{P}$ & $\mathrm{K}$ & $\mathrm{Ca}$ & $\mathrm{Mg}$ \\
\hline semente (E. grandis), área 1 & 130 & 2490 & 670 & 110 & 1000 \\
clone superior, área 2 & 110 & 2190 & 1440 & 70 & 1000 \\
clone inferior, área 2 & 100 & 1750 & 1660 & 70 & 1250 \\
semente, área 2 & - & & & & - \\
\hline
\end{tabular}

${ }^{1}$ Eficiência de uso dos nutrientes $=\left(\right.$ quantidade de serapilheira acumulada, $\left.\mathrm{kg} \mathrm{ha}^{-1}\right) \div$ (quantidade de nutriente acumulada na serapilheira, $\mathrm{kg} \mathrm{ha}^{-1}$ ). 
4.3. Configuração do sistema radicular de árvores propagadas por sementes e estacas

Quanto a distribuição das raizes finas no perfil de solo, constatou-se grandes variações entre materiais genéticos e época de amostragem (Figura 8 e Tabela 9). O clone superior apresentou-se como o genótipo mais plástico às variações ambientais e, o povoamento propagado por sementes (pps), o menos plástico. llustrando esta afirmação, pode ser visto claramente na Figura 8 que, no inverno, a densidade de raízes finas (drf) do clone superior foi maior nas camadas superiores do solo, até $30 \mathrm{~cm}$ de profundidade, e vice-versa no verão. Praticamente, não houve diferença entre os genótipos com relação a densidade cumulativa de raízes finas no perfil de solo, na amostragem feita no inverno (Figura 9). Cerca de $70 \%$ das raízes foram encontradas até $30 \mathrm{~cm}$ de profundidade. De forma diferente, no verão, a distribuição cumulativa de raízes finas do clone superior foi bem distinta daquela observada no inverno, onde apenas $30 \%$ das raizes finas foram encontradas nos $30 \mathrm{~cm}$ superficiais do solo. Ou seja, no verão as raízes deste genótipo se distribuiram mais homogeneamente pelo perfil do solo. Ao contrário, não foram observadas expressivas diferenças para os demais genótipos quanto a distribuição de raízes no perfil de solo.

Essa grande oscilação estacional da drf do clone superior evidencia sua grande capacidade de adaptação às condições adversas do meio ambiente, devendo ser este um fator preponderante para sua superioridade perante os outros genótipos. Assim, no verão, periodo de maior atividade metabólica das árvores, quando a demanda de água é muito alta, as árvores deste clone aumentam a drf em profundidade para absorver maior quantidade de solução do solo, consequentemente, também dos nutrientes dissolvidos nesta solução. Por outro lado, no inverno, com a redução do ritmo de crescimento das árvores, a drf nas camadas mais profundas é reduzida. A 


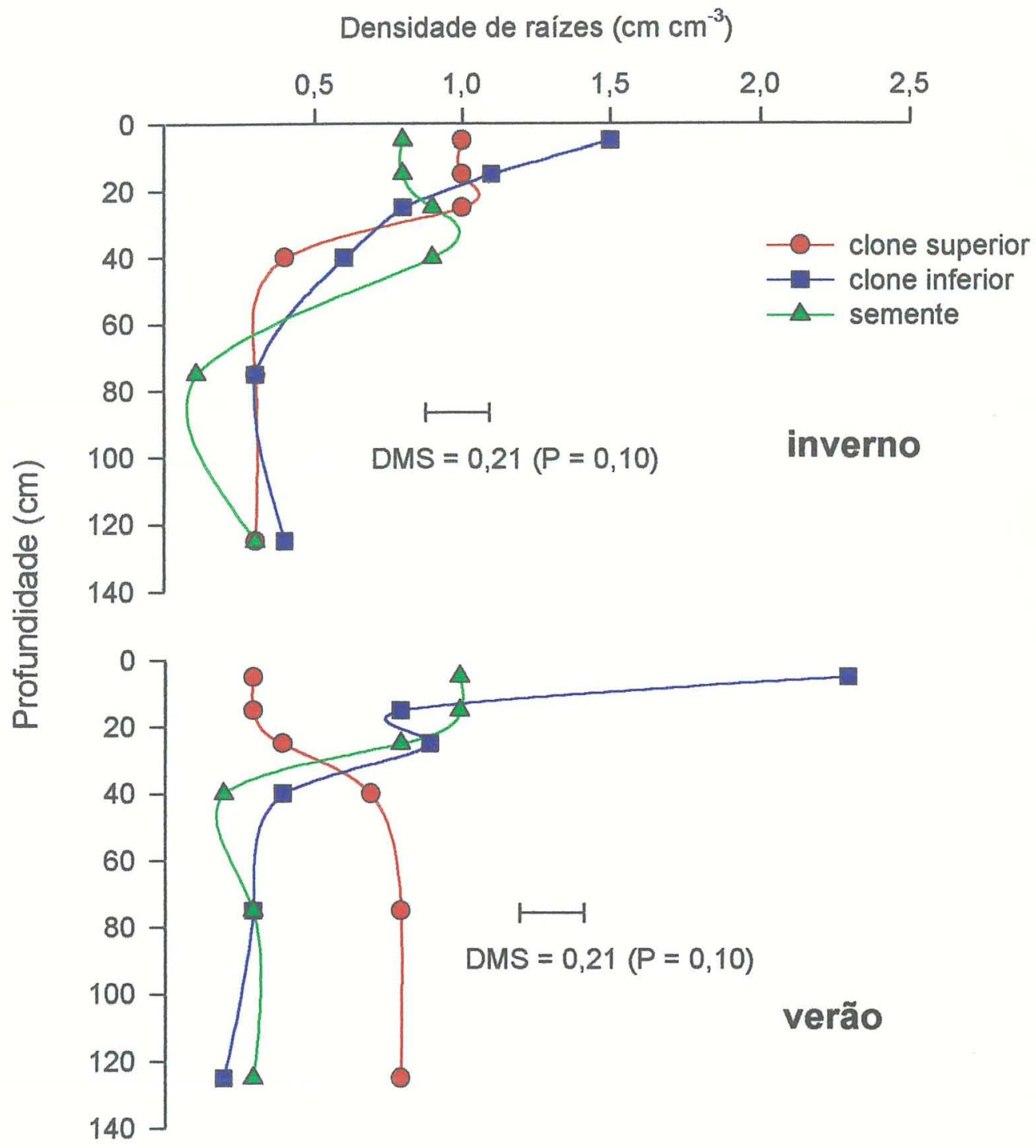

Figura 8. Densidade de raízes finas $(<3 \mathrm{~mm}$ ) aos 4,5 anos dos diferentes genótipos, amostradas com a sonda de $4 \mathrm{~cm}$ de diâmetro, no inverno (amostragem em 07/95) e verão (amostragem em 01/96), na área 2 (Moji Guaçu). 


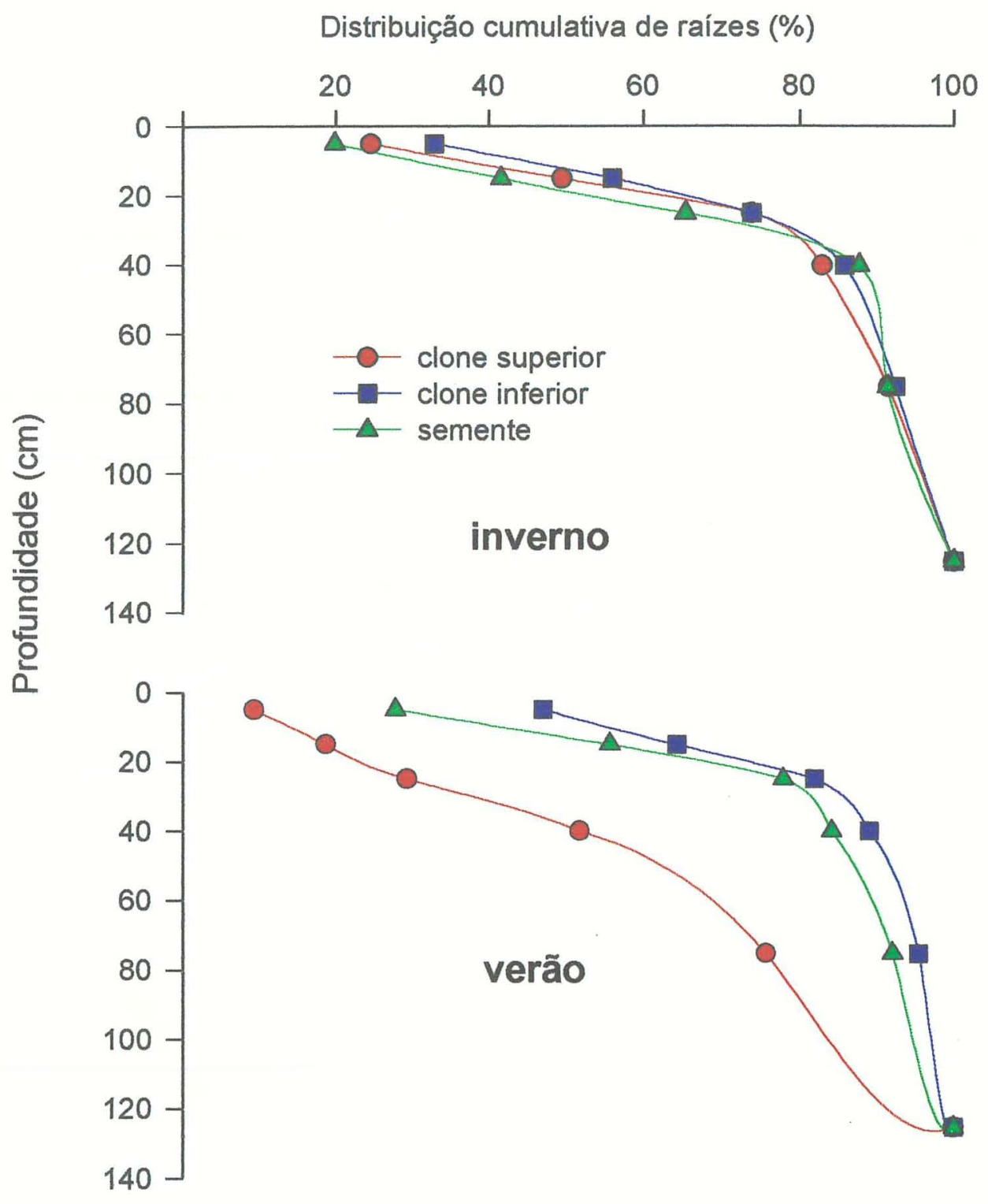

Figura 9. Distribuição cumulativa de raízes finas $(<3 \mathrm{~mm}$ ) aos 4,5 anos dos diferentes genótipos, amostradas com a sonda de $4 \mathrm{~cm}$, no inverno (amostragem em 07/95) e verão (amostragem em 01/96), na área 2 (Moji Guaçu). 
Tabela 9. Densidade de raízes finas ( $<3 \mathrm{~mm}$ ) na serapilheira e perfil de solo para os diferentes genótipos, no inverno (amostragem em 07/95) e verão (amostragem em 01/96) ${ }^{1}$, na área 2.

\begin{tabular}{|c|c|c|c|c|c|c|}
\hline \multirow{2}{*}{$\begin{array}{c}\text { Prof. } \\
\mathrm{cm}\end{array}$} & \multicolumn{3}{|c|}{ Inverno } & \multicolumn{3}{|c|}{ Verão } \\
\hline & Clone superior & Clone inferior & Semente & Clone superior & Clone inferior & Semente \\
\hline \multirow[b]{2}{*}{ serapilheira } & \multicolumn{6}{|c|}{$\mathrm{cm} \mathrm{cm}^{-2}$} \\
\hline & $7,4 \mathrm{~b} \mathrm{~A}$ & 29,0 a $A$ & 9,1 b B & 5,9 b A & 30,9 a $A$ & 25,9 a A \\
\hline & \multicolumn{6}{|c|}{$\mathrm{cm} \mathrm{cm}^{-3}$} \\
\hline $0-10$ & 1,0 ab $A$ & 1,5 a $B$ & $0,8 \mathrm{~b} \mathrm{~A}$ & 0,3 c B & $2,3 a A$ & $1,0 \mathrm{~b} \mathrm{~A}$ \\
\hline $10-20$ & 1,0 a $A$ & 1,1 a $A$ & 0,8 a $A$ & 0,3 b B & 0,8 a $A$ & 1,0 a $A$ \\
\hline $20-30$ & 1,0 a A & 0,8 a $A$ & 0,9 a $A$ & $0,4 \mathrm{~b} \mathrm{~B}$ & 0,9 a $A$ & 0,8 a $A$ \\
\hline $30-50$ & 0,4 b B & 0,6 b B & 0,9 a $A$ & 0,7 a $A$ & 0,4 b B & 0,2 b B \\
\hline $50-100$ & 0,3 a $B$ & 0,3 a $A$ & 0,1 b B & 0,8 a $A$ & 0,3 b A & $0,3 \mathrm{~b} \mathrm{~A}$ \\
\hline $100-150$ & 0,3 a $B$ & 0,4 a $A$ & 0,3 a $A$ & 0,8 a $A$ & $0,2 \mathrm{~b} \mathrm{~B}$ & $0,3 \mathrm{~b} \mathrm{~A}$ \\
\hline
\end{tabular}

${ }^{1}$ Médias com letras iguais não diferem significativamente ao nivel de $10 \%$ de probabilidade pelo teste de Tukey. Diferença entre genótipos (letras minúsculas) e épocas (letras maiúsculas). 
temperatura atmosférica e do solo, e o teor de água no solo devem ser os principais fatores reguladores desse processo (Roberts, 1976; Nambiar, 1983, Persson, 1995). Estes resultados demonstram a importância da plasticidade morfológica das raízes finas como estratégia adaptativa ao estresse hídrico e nutricional (Crick \& Grime, 1987), a qual também foi observada em Eucalyptus grandis por Mulligan \& Sands (1987). Para Dickmann et al. (1996), a estratégia adaptativa para 2 clones de híbridos de Populus spp, com o aumento do estresse hídrico, foi o rápido desenvolvimento de raízes finas além de $30 \mathrm{~cm}$ de profundidade no perfil do solo. A maior plasticidade morfológica das raizes finas do clone superior vem a corroborar com a afirmação feita por Comério ${ }^{3}$, na qual o clone superior é considerado um dos genótipos mais produtivos plantados pela CHAMPION PAPEL E CELULOSE Ltda., desde os solos mais ricos (latossolos) até os mais pobres (areias quartzozas). Neste genótipo, torna-se clara a existência de um eficiente mecanismo de "feedback" do sistema radicular quando as condições ambientais mudam (Adams et al, 1989).

A densidade de raízes finas ( $d r f$ na serapilheira foi muito superior àquela observada nas camadas de solo. Por exemplo, no inverno, a drf $(<1 \mathrm{~mm})$ do clone superior foi de $6,5 \mathrm{~cm} \mathrm{~cm}^{-2}$ e $0,93 \mathrm{~cm} \mathrm{~cm}^{-3}$, na serapilheira e no solo $(0-10 \mathrm{~cm})$, respectivamente (Tabelas 10 e 11). No outro extremo, esta diferença foi bem maior para o povoamento propagado por semente, de 43,8 $\mathrm{cm} \mathrm{cm}^{-2}$ e $0,7 \mathrm{~cm} \mathrm{~cm}^{-3}$, respectivamente, para os mesmos compartimentos. Este útimo valor é similar à $0,6 \mathrm{~cm} \mathrm{~cm}^{-3}(0-10 \mathrm{~cm})$, obtido por Baldwin \& Stewart (1987) num povoamento de Eucalyptus grandis aos 4 anos de idade. Em povoamentos jovens de Pinus radiata, a drf no solo variou de 0,05 a $0,32 \mathrm{~cm}$ $\mathrm{cm}^{-3}$, em povoamentos mais velhos, de 0,8 a $5,0 \mathrm{~cm} \mathrm{~cm}^{-3}$ (Squire et al., 1978).

\footnotetext{
${ }^{3}$ COMÉRIO, J. (CHAMPION PAPEL E CELULOSE Ltda.) - Comunicação pessoal, 1992.
} 
Tabela 10. Densidade de raizes finas $(<3 \mathrm{~mm}$ ) encontrada na serapilheira de diferentes genótipos em duas épocas de amostragem ${ }^{3}$.

\begin{tabular}{|c|c|c|c|}
\hline \multirow[t]{2}{*}{ Classe de diâmetro } & \multirow[t]{2}{*}{ Genótipo } & \multicolumn{2}{|c|}{ Eроса } \\
\hline & & Inverno & Verão \\
\hline & & & \\
\hline \multirow[t]{3}{*}{$<1 \mathrm{~mm}$} & clone superior & $6,5 \mathrm{~b} \mathrm{~A}$ & 5,5 b B \\
\hline & clone inferior & 26,9 a $B$ & 30,3 a $A$ \\
\hline & semente & 42,8 a $A$ & 25,2 a $B$ \\
\hline \multirow[t]{3}{*}{1 a $3 \mathrm{~mm}$} & clone superior & $1,6 \mathrm{~b} \mathrm{~A}$ & 0,8 a A \\
\hline & clone inferior & $2,4 a b A$ & 1,1 a $B$ \\
\hline & semente & 1,0 a $A$ & 1,2 a $A$ \\
\hline \multirow[t]{3}{*}{ total } & clone superior & 8,1 b A & $6,3 \mathrm{~b} \mathrm{~A}$ \\
\hline & clone inferior & 29,3 b A & 31,4 a $A$ \\
\hline & semente & 43,8 a $A$ & 26,4 a $B$ \\
\hline
\end{tabular}

\footnotetext{
${ }^{1}$ As médias com letras iguais não diferem significativamente ao nível de $10 \%$ de probabilidade pelo teste de Tukey. Diferença entre genótipos (letras minúsculas) e épocas (letras maiúsculas).
} 


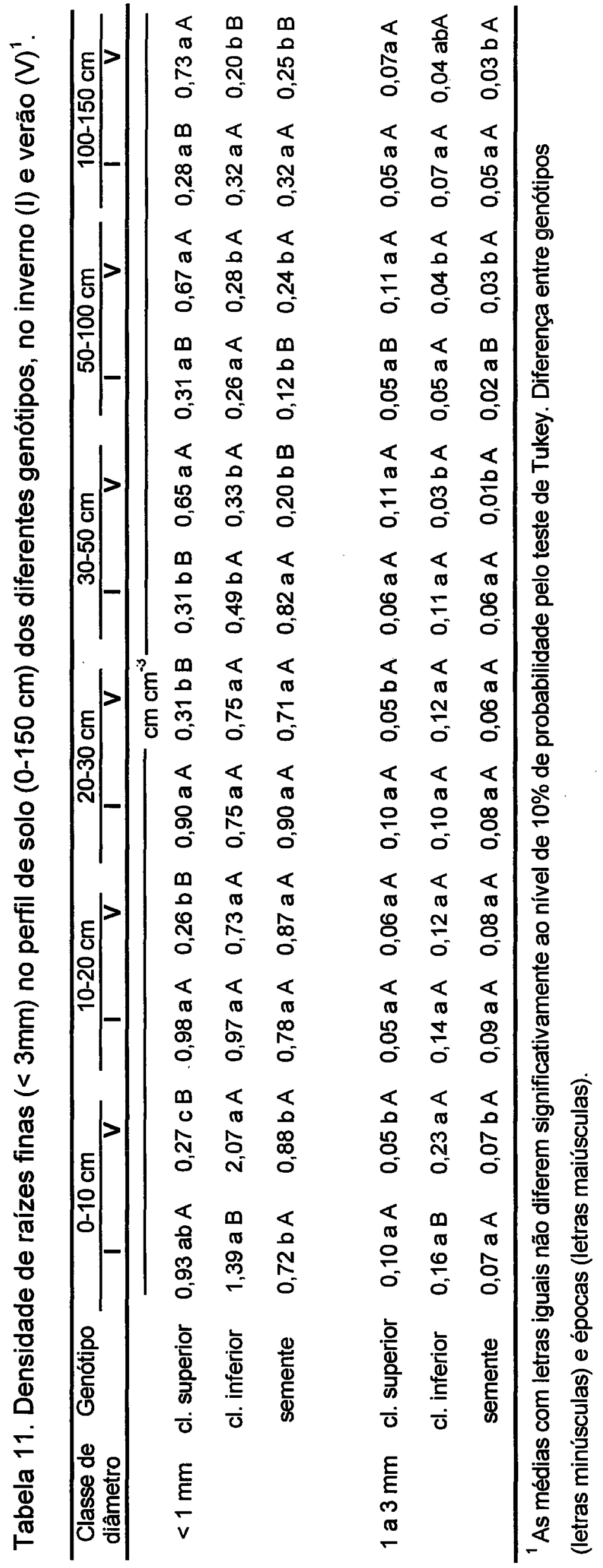


Ainda com relação a drf, foi verificado que os genótipos menos produtivos tendem a ter uma maior quantidade de raizes finas nas camadas superficiais do solo e na serapilheira, principalmente no verão. Esse comportamento não pode ser atribuído a diferenças nas características físicas e químicas dos solos sob os povoamentos estudados, porque elas não se distinguem acentuadamente entre (Tabelas 1 e 2). Perante os dados obtidos, parece que a disponibilidade de água é o principal fator a afetar a drf nas camadas mais profundas do solo $(>30 \mathrm{~cm}$ ) e a disponibilidade de nutrientes o principal fator a afetar a drf nas camadas superficiais do solo $(<30 \mathrm{~cm})$ e na serapilheira.

$\mathrm{Na}$ figura 10 , a menor disponibilidade de água nas camadas mais profundas do solo sob o clone superior ilustram a provável existência de zonas de depleção nesta região, ao mesmo tempo que apresentam maior drf. É importante ressaltar que em solos de baixa fertilidade, como os do presente estudo, uma das principais fontes de nutrientes para as árvores vem dos processos de ciclagem biogeoquímica de nutrientes, disponibilizados por intermédio da mineralização da matéria orgânica presente, predominantemente, nas raízes finas em decomposição ( Fabião et al., 1995) e resíduos vegetais depositados sobre o solo (Rode, 1995). Deste ponto de vista, os genótipos menos produtivos ampliam sua área radicular para aumentar as possibilidades de absorção dos nutrientes presentes nestes componentes, que, apesar de serem acumulados em maior quantidade nos povoamentos dos genótipos menos produtivos, possuem em seus tecidos menor concentração de nutrientes.

O comprimento de raízes $(<1 \mathrm{~mm})$, no verão, variou de 5.500 a $25.200 \mathrm{~km} \mathrm{ha}^{-1}$ na serapilheira e, de 91.400 a $53.100 \mathrm{~km} \mathrm{ha}^{-1}$ no perfil de solo, para o clone superior e pps, respectivamente (Tabela 12). Ou seja, cada árvore do clone superior tem, em média, cerca de $55 \mathrm{~km}$ de raízes finas 
Teor de águra no solo (\%)

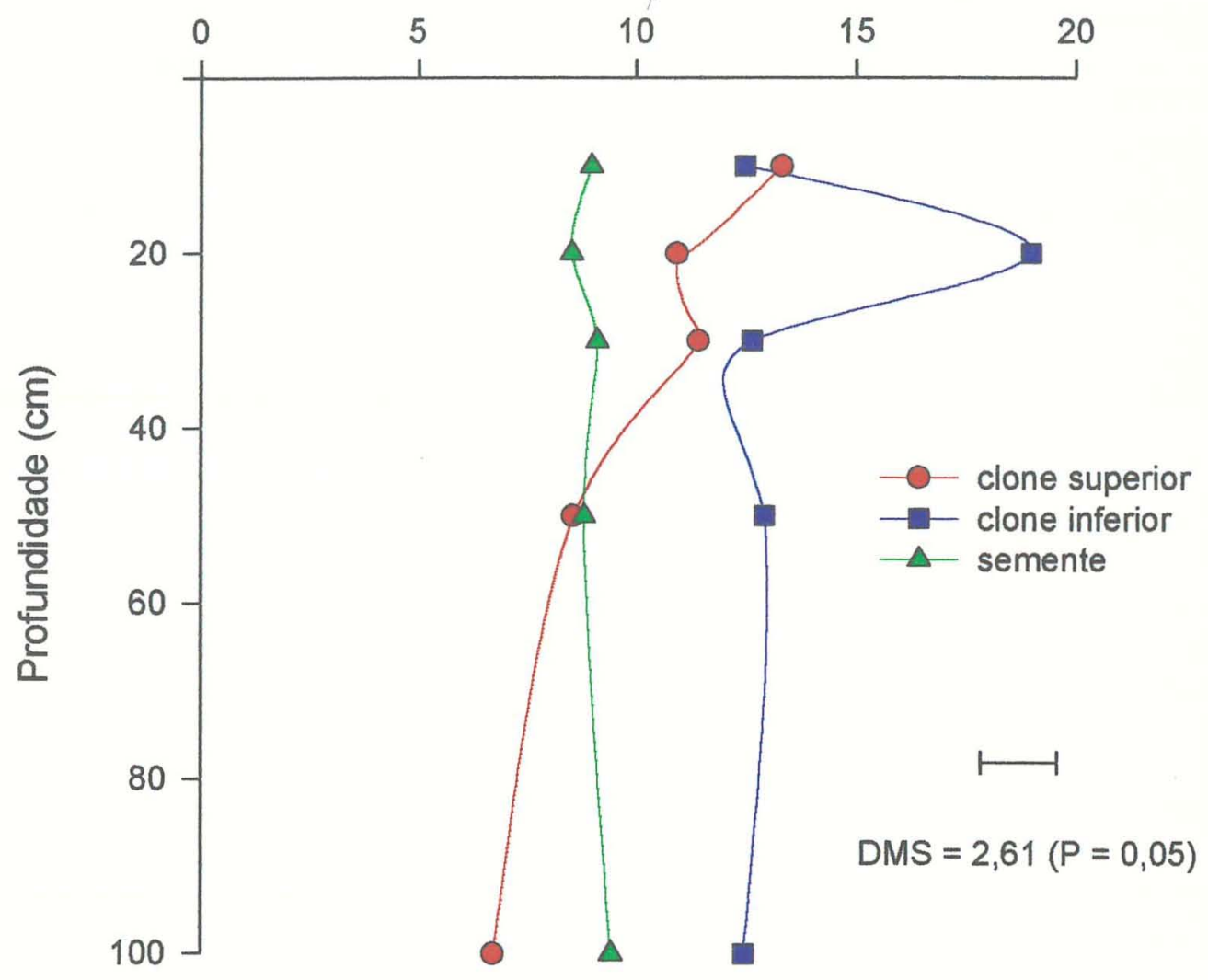

Figura 10. Teor de água no solo sob diferentes genótipos (amostragem em janeiro de 1995). 


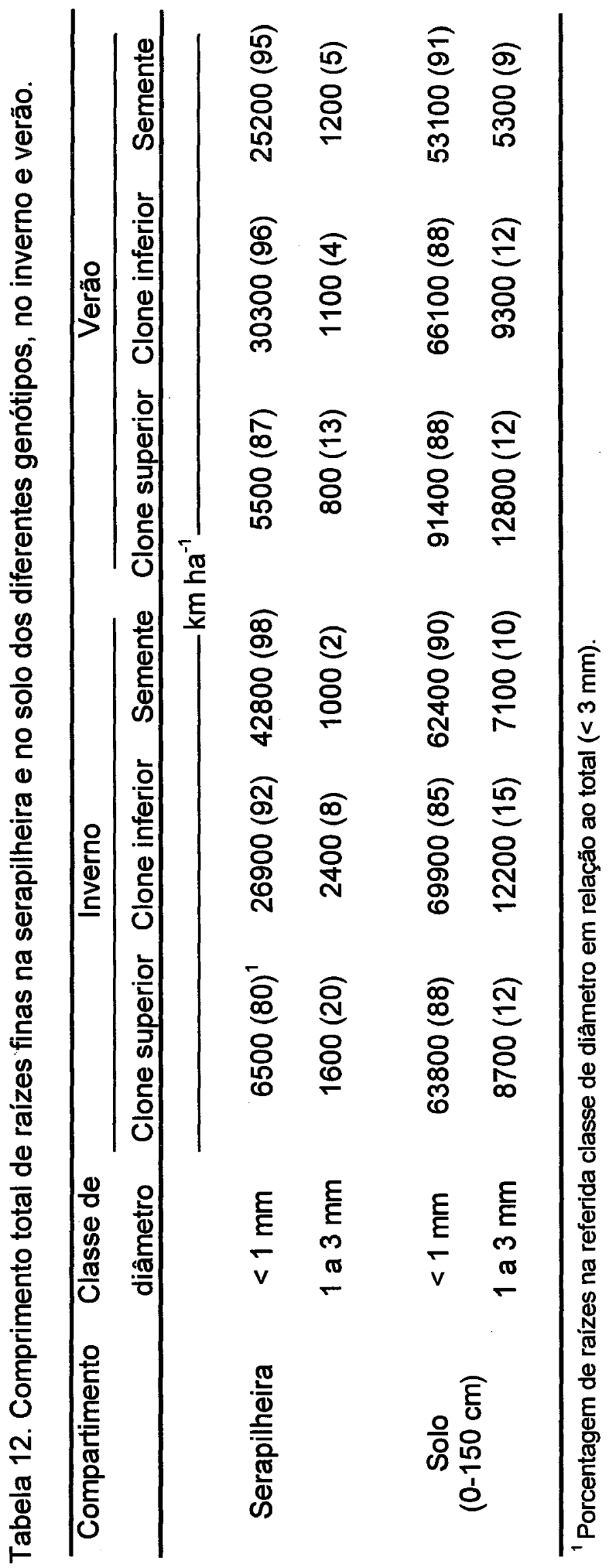


$(<3 \mathrm{~mm})$, contra $32 \mathrm{~km}$ do genótipo propagado por semente. Para o clone inferior foi encontrado um valor médio de $42 \mathrm{~km}$ por árvore. Novamente, frisando o que foi escrito anteriormente, os clones apresentaram suas maiores extensões de raízes no solo e, menor, na serapilheira; o pps vice-versa. Tudo indica que a extensão de raízes finas é uma característica intrínseca (fator hereditário) do genótipo, a qual é estreitamente relacionada com seu comportamento nutricional, potencial produtivo e capacidade de adaptação à condições de estresse ambiental. Afirmações semelhantes foram feitas por Nambiar et al. (1982), nas quais destacam a alta herdabilidade dos parâmetros radiculares como importante ferramenta para o melhoramento genético.

Ainda sobre a grande oscilação estacional da quantidade de raizes finas, os dados obtidos revelam que esta oscilação, operacionalizada por intermédio da síntese e "morte" de raízes, tem grande importância para a ciclagem biogeoquímica de nutrientes e enriquecimento das camadas do solo com matéria orgânica; por conseguinte, também, para a ativação dos microorganismos e fauna do solo. Observou-se que entre as amostragens efetivadas no inverno e verão, houve uma variação de 1194,6, 1221,1 e 589,5 $\mathrm{kg} \mathrm{ha}^{-1}$ de biomassa de raízes finas, para o clone superior, clone inferior e pps, respectivamente (Tabela 13). Isto corresponde a $7,4 \mathrm{~kg} \mathrm{ha}^{-1}$ de $\mathrm{N}, 0,5 \mathrm{~kg} \mathrm{ha}^{-1}$ de $\mathrm{P}, 0,3 \mathrm{~kg} \mathrm{ha}^{-1}$ de $\mathrm{K}$ e 5,7 kg ha-1 de Ca disponibilizados via decomposição de raízes finas, no solo e serapilheira, para o clone superior (Tabela 14). Persson (1980) encontrou uma taxa de renovação de $1830 \mathrm{~kg} \mathrm{ha}^{-1}$ em povoamento de Pinus sylvestris, aos 20 anos de idade. Mcclaugherty el al. (1982) obtiveram, em povoamento de Pinus spp com 1 ano de idade, uma produção de raízes finas $\left(<3 \mathrm{~mm}\right.$ ) de $3,2 \mathrm{t}$. ha ${ }^{-1} \mathrm{ano}^{-1}$ e $44 \mathrm{~kg} \mathrm{ha}^{-1}$ de $\mathrm{N}$ disponibilizados neste período. No entanto, a quantidade de nutrientes disponibilizados a partir das raizes finas deve ser significativamente maior, já que parte dos nutrientes foram perdidos durante a separação e acondicionamento das raízes. Misra (1994) comprovou num experimento com Eucalyptus nitens que $24 \%$ do $\mathrm{K}$ foi 
Tabela 13. Biomassa de raizes finas $(<3 \mathrm{~mm}$ ) na serapilheira e no solo dos diferentes genótipos, no inverno e verão, na área 2

\begin{tabular}{|c|c|c|c|c|c|c|}
\hline \multirow[b]{2}{*}{ Prof. } & \multicolumn{3}{|c|}{ Inverno } & \multicolumn{3}{|c|}{ Verão } \\
\hline & Clone superior & Clone inferior & Semente & Clone superior & Clone inferior & Semente \\
\hline $\mathrm{cm}$ & & & $-\mathrm{kg}$ & $\mathrm{ha}^{-1}$ & & \\
\hline serapilheira & 291,8 & 1206,9 & 238,7 & 151,2 & 1021,2 & 191,0 \\
\hline $0-10$ & 274,1 & 765,9 & 348,2 & 208,9 & 1193,7 & 486,3 \\
\hline $10-20$ & 495,1 & 736,1 & 547,1 & 521,7 & 775,9 & 437,7 \\
\hline $20-30$ & 618,9 & 468,6 & 228,8 & 570,3 & 342,2 & 198,9 \\
\hline $30-50$ & 972,6 & 804,6 & 358,1 & 618,9 & 363,8 & 198,9 \\
\hline $50-100$ & 905,2 & 1273,2 & 534,3 & 486,8 & 392,2 & 215,3 \\
\hline $100-150$ & 454,7 . & 409,3 & 204,6 & 260,0 & 354,5 & 143,2 \\
\hline
\end{tabular}

Tabela 14. Quantidade de nutrientes disponibilizados via decomposição de raizes finas, no solo e serapilheira a partir dos diferentes genótipos estudados.

\begin{tabular}{cccccc}
\hline Genótipo & $\mathrm{N}$ & $\mathrm{P}$ & $\mathrm{K}$ & $\mathrm{Ca}$ & $\mathrm{Mg}$ \\
\cline { 2 - 6 } & & & $\mathrm{Kg} \mathrm{ha}{ }^{-1}$ & & \\
clone superior & 7,4 & 0,5 & 0,3 & 5,7 & 1,1 \\
clone inferior & 6,9 & 0,5 & 0,2 & 4,7 & 1,1 \\
semente & 4,7 & 0,4 & 0,1 & 3,3 & 0,4 \\
\hline
\end{tabular}


perdido na lavagem das raízes e 16, 50 e $46 \%$ dos teores de $N, P$ e K foram perdidos em solução aquosa na qual as raizes ficaram submersas. Outra grande dificuldade é a separação de raízes vivas e mortas, as quais podem apresentar uma composição química muito diferente, em razão de seu estado fisiológico.

De modo geral, tanto para a serapilheira como para o solo, verificou-se que mais de $90 \%$ das raízes finas pertenciam a classe de raízes $<1 \mathrm{~mm}$ (Tabela 12), indicando ser as raízes dessa espessura as principais responsáveis pelos processos de absorção de água e nutrientes. A partir de um estudo de distribuição e crescimento radicular de Pinus sylvestris, Roberts (1976) concluiu que mais de $90 \%$ do comprimento radicular consistia de raízes menores que $0,5 \mathrm{~mm}$ de diâmetro, confirmando a importância desta classe de raízes como superfície de contato com o solo. Baldwin \& Stewart (1987) constataram que raízes de Eucalyptus grandis com diâmetro $\leq 1 \mathrm{~mm}$ contribuíram com $85 \%$ do comprimento total de raízes; porém, apenas $20 \%$ do peso total de raízes se referia a esta classe. Assim, não se recomenda uso da massa seca de raízes no ajuste de modelos para estimativa do comprimento radicular, sem que haja a separação das raízes em classes de diâmetro.

\subsection{Comparação entre métodos de amostragem de raizes finas}

As médias de densidade de raízes finas (drf) obtidas pelos métodos do monolito e da sonda de $4 \mathrm{~cm}$, para a maioria dos genótipos e camada de amostragem, foram estatisticamente semelhantes (Figura 11). Dentre os dezoito conjuntos de médias apresentados na Figura 11, apenas três pares, relativas às camadas 20-30 e $30-50 \mathrm{~cm}$, não foram estatisticamente semelhantes entre si, o que pode ser atribuído aos altos níveis de imprecisão dos métodos de amostragem de raízes, que é reflexo da grande variabilidade 

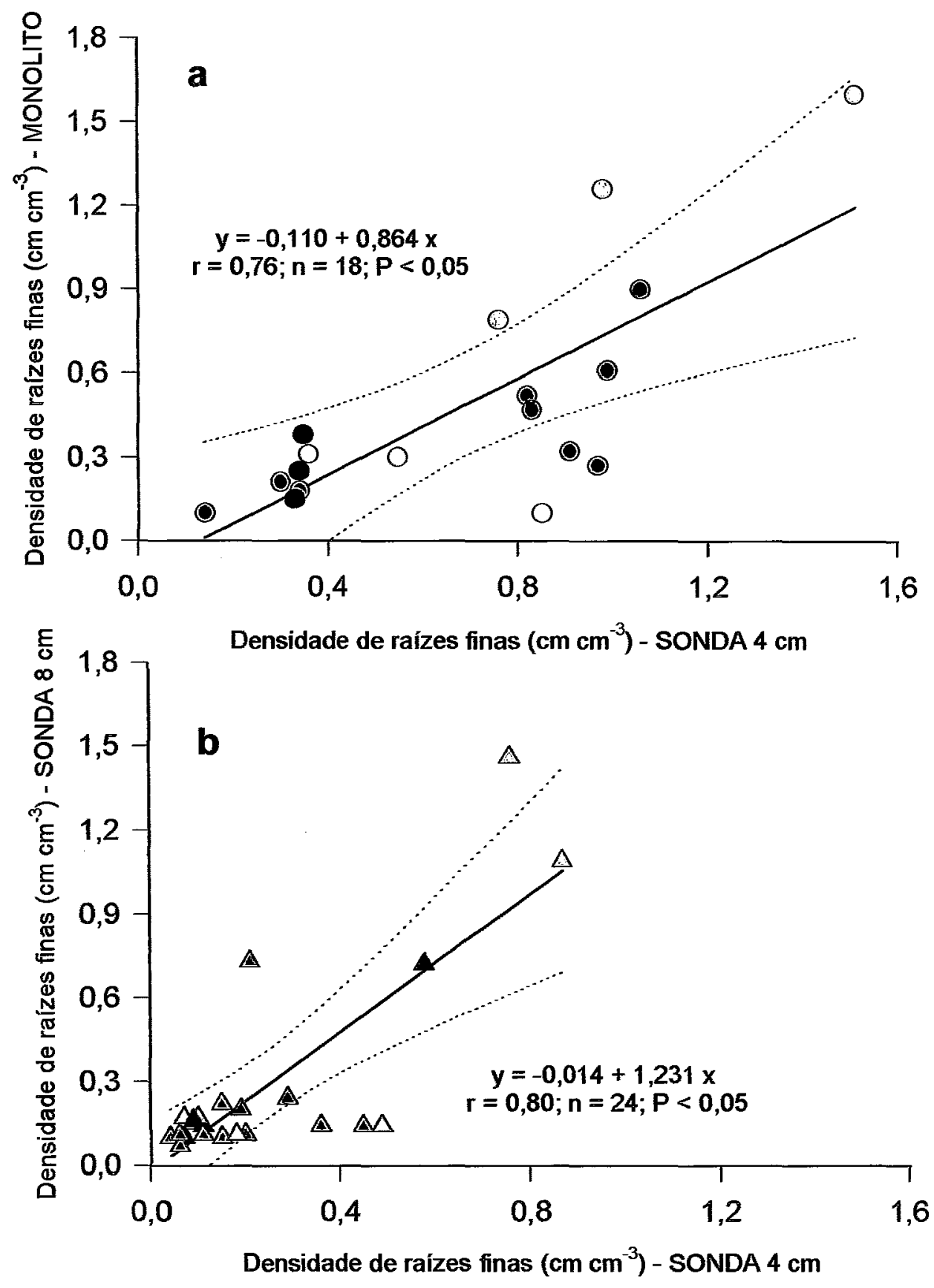

Figura 11. Análise de correlação entre densidade média de raízes finas $(<3 \mathrm{~mm})$, incluindo os dados de todas as camadas do solo e genótipos, obtidas pela amostragem com a sonda de $4 \mathrm{~cm}$ e monolitos (a) e entre as sondas de 4 e $8 \mathrm{~cm}$ (b). As linhas pontilhadas correspondem ao intervalo de confiança com $99 \%$ de probabilidade. As profundidades são: 0-10 (azul-claro), 10-20 (azul), 20-30 (vermelho), 30-50 (amarelo), 50-100 (verde) e 100-150 (preto). 
espacial de distribuição das raízes finas (Gonçalves, 1994) e, também, devido a fatores intrínsecos aos próprios métodos (Persson, 1983).

Os dados de drf obtidos pelas sondas de 4 e $8 \mathrm{~cm}$ de diâmetro e pela extração de monolitos apresentaram-se altamente correlacionados entre si (Figura 11). O grande nível de semelhança entre médias e o alto grau de correlação entre os dados obtidos com a amostragem de raízes via remoção de monolitos e com a sonda de $4 \mathrm{~cm}(r=0,76 ; P<0,01$; $n=18$ ) evidencia que esse método pode ser substituído pela sonda, sem comprometimento da precisão de amostragem. Isso traz vários benefícios para o estudo de raízes finas, pois o método das sondas é pouco destrutivo, menos oneroso e de maior rendimento operacional. Além disso, raízes de maior diâmetro não são coletadas pela sonda, proporcionando um volume de solo contendo exclusivamente raizes finas, o que não é possivel pela remoção de monolitos.

Com relação aos dados obtidos com as sondas de 4 e $8 \mathrm{~cm}$, verificou-se que eles são altamente correlacionados entre si $(r=0,80 ; P<0,01$; $n=24$ ), indicando que as raízes finas podem ser amostradas com uma sonda de menor diâmetro, sem que haja comprometimento da precisão de amostragem. Com isso, pode-se elevar consideravelmente os rendimentos operacionais e reduzir os custos de amostragem. $O$ equipamento de amostragem terá dimensões menores, sendo mais leve e fácil de transportar e manejar. Além disso, as amostras de solo e raízes serão menores, facilitando a lavagem e separação das raízes, bem como a digitalização de suas imagens. $O$ uso de uma sonda de menor diâmetro, como a de $4 \mathrm{~cm}$ de diâmetro, reduz a possibilidade de perda de parte das amostras durante suas remoções, sobretudo nos solos menos coesos, mais arenosos, como os do presente estudo (área 1). Ao comparar o método do monolito com a sonda, estimou-se um ganho superior a $50 \%$ nos rendimentos operacionais, que vão desde a 
amostragem no campo até a digilitalização das imagens das raizes. Na época do verão, com níveis mais elevados de umidade do solo, a eficiência de amostragem foi maior, devido a menor resistência do solo à penetração da sonda, bem como, devido a menor fragmentação das amostras de solo-raiz. Contudo, não se recomenda o uso da sonda sob altos níveis de umidade do solo (acima de $80 \%$ da capacidade de campo), pois a aderência e deformação das amostras são muito grandes. Observou-se que os rendimentos operacionais são mais baixos nos pontos de amostragem mais próximos ao tronco das árvores, porque a concentração de raízes laterais, grossas, são maiores. 


\section{CONCLUSÕES}

A despeito das maiores quantidades acumuladas, os clones produziram mais unidades de peso de biomassa por unidade de peso de $N, P$, $\mathrm{K}$ e $\mathrm{Mg}$ estocadas (maior eficiência de uso desses nutrientes) do que o povoamento propagado por sementes (pps), sendo essa eficiência muito mais acentuada para $\mathrm{P}, \mathrm{K}$ e Mg. Por outro lado, este clone foi muito menos eficiente no uso de Ca relativamente ao pps.

A distribuição e variação estacional da quantidade de raizes finas no perfil do solo apresentaram-se como características estreitamente relacionadas com a capacidade de adaptação dos genótipos aos estresses hídrico e térmico do solo, afetando diretamente seus potenciais produtivos. $O$ clone superior (hibrido E. grandis vs. E. urophylla), genótipo mais produtivo, mostrou-se plástico enquanto que o clone inferior ( $E$. grandis) e o povoamento de E. grandis propagado por sementes, genótipos menos produtivos, mostraram-șe pouco plásticos às variações sazonais.

Mais de $90 \%$ das raizes finas dos genótipos pesquisados possuíam espessura $\leq 1 \mathrm{~mm}$.

A densidade de raízes finas ( $d r f)$ na serapilheira foi muito superior àquela observada nas diferentes camadas do solo. No inverno, a drf ( $<1 \mathrm{~mm}$ ) do clone superior foi de $6,5 \mathrm{~cm} \mathrm{~cm}^{-2}$ e $0,93 \mathrm{~cm} \mathrm{~cm}^{-3}$ na serapilheira $e$ no solo $(0-10 \mathrm{~cm})$, respectivamente. 
Os genótipos menos produtivos apresentam uma tendência de maior quantidade de raízes finas nas camadas superficiais do solo e na serapilheira, principalmente no verão. Oa resultados indicam que a disponibilidade de água é o principal fator que influencia a drf nas camadas mais profundas do solo $(>30 \mathrm{~cm})$ e a disponibilidade de nutrientes a principal variável a afetar a drf nas camadas superficiais do solo $(<30 \mathrm{~cm})$ e na serapilheira.

Cada árvore do clone superior possui em média $55 \mathrm{~km}$ de raízes finas ( $<3 \mathrm{~mm}$ ), contra $32 \mathrm{~km}$ do genótipo propagado por semente. Para o clone inferior foi encontrado um valor médio de $40 \mathrm{~km}$ por árvore. Tudo indica que a extensão de raízes finas é uma característica intrínseca (fator hereditário) do genótipo, a qual é estreitamente relacionada com seu comportamento nutricional, potencial produtivo e capacidade de adaptação à condições de estresse ambiental.

O método do monolito para amostragem de raízes finas apresentou niveis de precisão similar aos obtidos com a sonda de $4 \mathrm{~cm}$ de diâmetro. $(r=0,76 ; p<0,05)$. As sondas de 4 e $8 \mathrm{~cm}$ apresentaram niveis de precisão de amostragem semelhantes $(r=0,80 ; p<0,05)$. Os ganhos operacionais com o uso da sonda menos espessa foram cerca de 30 a $50 \%$ superiores aos obtidos com a sonda de $8 \mathrm{~cm}$, dependendo da época e posição de amostragem. Assim sendo, considera-se que a sonda de $4 \mathrm{~cm}$ é mais adequada do que a sonda de $8 \mathrm{~cm}$ de diâmetro, especialmente para os solos mais arenosos (menos coesos), em virtude da menor perda e deformação das amostras de solo com raízes. 
Os resultados de comprimento de raízes, decorrente do uso e processamento de imagens digitais através do sistema SIARCS, foram altamente significativos, o qual é indicado para futuros trabalhos dada sua confiabilidade e rapidez no processamento dos dados. 


\section{REFERÊNCIAS BIBLIOGRÁFICAS}

ABER, J. D.; MELILLO, J. M.; NADELHOFFER, K. J. ; McCLAUGHERTY, C. A.; PASTOR, J. Fine root turnover in forest ecosystems in relation to quantity and form of nitrogen availability: a comparison of two methods. Oecologia, v. 66, p.317-321, 1985.

ADAMS, M. B.; PENNELL, D.; CAMPBELL, R. G. Fine root distribution in a young loblolly pine (Pinus taeda L.) stand: Effects of preplant phosphorus fertilization. Plant and Soil, v. 113, p. 275-278, 1989.

AHLSTRÖM, K.; PERSSON, H.; BÖRJESSON, I.. Fertilization of a mature Scots pine (Pinus sylvestris L.) stand - efects on fine roots. Plant and Soil, v. 106, p. $179-190,1988$.

ASHTON, D. H. Studies on mycorryizae of Eucalyptus regnans F. Muell. Australian Journal Botany, v. 24, p. 723-741, 1976.

AXELSSON, E.; AXELSSON, B. Changes in carbon allocation patterns in spruce and pine trees following irrigation and fertilization. Tree Physiology, v. 2, p. 189-204, 1986.

BALDWIN, P. J.; STEWART, H. T. L. Distribution, lenght and weight of roots in young plantations of Eucalyptus grandis W. Hill ex Maiden irrigated with recycled water. Plant and Soil, v. 97, p.243-252, 1987.

BERISH, C. W.; EWEL, J. J. Root development in simple and complex tropical succecional ecosystems. Plant and Soil, v. 108, p. 73-84, 1988. 
BOEHLE, J.; KRESGE, W. H.; KARDOS, L. T. Apparatus for taking soil-root cores. Agronomy Journal, v. 55, p.208-209, 1963.

BÖHM, W. Methods of studying root systems. Berlim: Springer-Verlag, 1979. 188p.

BORGES, E. N.; NOVAIS, R. F. DE; BARROS, N. F. DE; COSTA. L M. DA; NEVES, J. C. L. Respostas de mudas de eucalipto a camadas compactadas de solo. Revista Árvore, v. 10, n. 2, p. 181-195, 1986.

BOWEN, G.D.. Effects of soil temperature on root growth and phosphate uptake along Pinus radiata roots. Australian Journal of Soil Research. v. 8, p.3142, 1970.

BRAGG, P. L.; GOVI, G.; CANNELL, R. Q. A comparison of methods, including angled and vertical minirhizotrons, for studying root growth and distribution in a spring oat crop. Plant and Soil, v. 73, p.435-440, 1983.

CAMARGO, O. A. Compactação do solo e desenvolvimento de plantas. Campinas: Fundação Cargill, 1983. 44p.

CARBON, B. A.; BARTLE, G. A.; MACPHERSON, D. K. The distribution of root lenght, and the limits to flow of soil water to roots in a dry sclerophyll forest. Forest Science, v. 26, n. 4, 1980, p.656-664, 1980.

CRESTANA, S.; GUIMARÃES, M; F.; JORGE, L. A. C.; RALISCH, R.; TOZZI, C. L.; TORRE, A.; VAZ, C. M. P. Avaliação da distribuição de raízes no solo auxiliada por processamento de imagens digitais. Revista Brasileira de Ciência do Solo. v. 18, p. 365-371, 1994. 
COUTO, H. T. Z. DO Índice de sítio. In: Relatório Interno da Champion Papel e Celulose Ltda., Moji Guaçu, São Paulo, 1990. 7p.

CRICK, J. C.; GRIME, J. P. Morphological plasticity and mineral nutrient capture in two herabceous species of contrasted ecology. New Phytologist, v. 107, n. 2, p. 403-414, 1987.

DAVIS, G. R.; NIELSEN, W. A.; McDAVITT, J. G., . Root distribution of Pinus radiata related to soil characteristcs in five Tasmaniam soils. Australian Journal Șoil Research v. 21, p. 165-71, 1983.

DEANS, J. D. Flutuactions of the soil enviroment and fine root growth in a young sikta spruce plantation. Plant and Soil, v. 52, p. 195-208, 1979.

DICKMANN, D. I.; NGUYEN, P. V.; PREGITZER, K. S. Effects of irrigation and coppicing on above-ground growth, physiology, and fine root dynamics of two field-grown hybrid poplar clones. Forest Ecology and Management, 80, p.163-174, 1996.

EIS, S. Root system morphology of western hemlock, western red cedar and Douglas fir. Canadian Journal of Forest Research, v. 4, p. 28-38, 1974

FABIÃO, A.; PERSSON, H. A.; STEEN, E. Growth dynamics of superficial roots in Portuguese plantations of Eucalyptus globulus Labill. studied with a mesh bag technique. Plant and Soil, v. 83, n. 2, p.233-242, 1985.

FABIÃO, A.; MADEIRA, M.; STEEN, E.; KÄTTERER, T.; RIBEIRO, C.; ARAÚJO, C. Development of root biomass in a Eucalyptus globulus 
plantation under different water and nutrient regimes. Plant and Soil, v.168-169, p.215-223, 1995.

FELLER, M. Biomass and nutrient distribution in two eucalypt forest ecosystems. Australian Journal of Ecology, v. 5, p. 309-333, 1980.

FOGEL, R.; HUNT, G. Fungal and arboreal biomass in a western Oregon Douglas-fir ecossystem: Distribution patterns and turnover. Canadian Journal Forest Research, v. 245-256, 1979.

FOGEL, R. Mycorrhizae and nutrient cycling in natural forest ecossystems. New Phytologist, v.86, p.199-212, 1980.

FOGEL, R. Root turnover and productivity of coniferous forests. Plant and Soil, v.71, p. 75-85, 1983.

FORD, E. D.; DEANS, J. D. Growth of sikta spruce plantation spatial distribution and seasonal fluctuations of lenghts, weights and carboydrats concentrations of fine roots. Plant and Soil, v. 47, p.463-485, 1977.

FORD, E. D.; DEANS, J. D. The effects of canopy structure on stemflow, trhoughfall and intercpetion loss in a yong Sitka spruce plantation. Journal of Applied Ecology, v. 15, p.905-917, 1978.

GONÇALVES, J. L. M. Características do sistema radicular de absorção do Eucalyptus grandis sob diferentes condições edáficas. Piracicaba, 1994. 84p. Tese (Livre Docência) - Escola Superior de Agricultura "Luiz de Queiroz", Universidade de São Paulo. 
GREACEN, E. L.; SANDS, R. Compaction of forest soil. Australian Journal Forest Research, v. 18, p. 163-189, 1980.

HENDRICKSON, O. Q.; ROBINSON, J. B. Effects of roots and litter on mineralization processes in forest soil. Plant and Soil, v. 80, n. 3, p.391405, 1984.

JON VAN LIER, QUIRIYN DE Extração de água do solo por plantas desenvolvimento e validação de um modelo. Piracicaba, 1994. p. Tese (Doutorado) - Escola Superior de Agricultura "Luiz de Queiroz", Universidade de São Paulo.

JORGE, L. A. C.; RESENDE, P. C. S.; POSADAS DURAND, A.; FREITAS JUNIOR, E.; CRESTANA, S. Comparação de técnicas de análises de imagens digitais na determinação do comprimento de raizes. In: Resumos da X Reunião Brasileira de Manejo e Conservação do Solo e da Água. p.314-315, 1993.

KEMPER, B.; DERPSCH, R. Soi compaction and root growth in Paraná. In: Russel, R. S., Igue, K.; Mehta, Y. R. eds. The soil/root system in relation to Brazilian Agriculture. Londrina, Fundação Instituto Agronômico do Paraná, 1981. p. 81-101.

KEYES, M. R.; GRIER, C. C. Above and belowground net production in 40 yearold Douglas fir stands on low and high productivity sites. Canadian Jounal of Forest Science, v. 11, p.599-605, 1981.

KÖPKE, U. Methods For Studying Root Growth. In: RUSSEL, R. S.; KOZEN, I. \& METHA, Y.R. Procedings Of The Symposium On The Soil/Root 
System. INSTITUTO AGRONÔMICO DO PARANÁ - IAPAR. Londrina, Paraná, Brazil, 1981. p.303-318.

LELES, P. S. DOS S. Crescimento, alocação de biomassa e distribuição de nutrientes e uso de água em $E$. camaldulensis e $E$. pellita sob diferentes espaçamentos. Viçosa, 1995, 133 p. Dissertação (M.S.) - Universidade Federal de Viçosa.

LYFORD, W. H. Rhizography of non-wood roots of trees in the forest floor. In:TORREY, J.; CLARKSON, D. T. (Ed.) The development and function of roots. New York: Academic Press, 1975, p.179-196.

LÖHMUS, K.; IVASK, M. Decomposition and nitrogen dynamics of fine roots of Norway spruce (Picea abies (L.) Karst.) at different sites. Plant and Soil, v. 168-169, p.89-94, 1995.

MARSH, B. B. Measurement of lenght in random arrangements of lines. Journal of Applied Ecology. v. 8, p. 265-267, 1971.

MCCLAUGHERTY, C. A.; ABER, J. D.; MELILLO, J. M The role of fine roots in the organic matter and nitrogen budgets of two forested ecosystems. Ecology, v. 63, n. 5, p.1481-90, 1982.

MAJDI, H.; PERSSON, H. Effects of ammonium sulphate application on the chemistry of bulk soil, rhizosphere, fine roots and fine root distribution in a Picea abies (L.) Karst. stand. Plant and Soil, v.168-169, p.151-160, 1995.

MACFALL, J. S.; JOHNSON, G. A.; KRAMER, P. J. Comparative water uptake by roots of different ages in seedlings of loblolly pine (Pinus taeda L.). New Phytologist, v. 119, p. 551-560, 1991. 
MEIER, C. E.;GRIER, C.; COLE, D. W. Below and aboveground $N$ and $P$ use by Abies amabilis stands. Ecology, v. 66, p. 1928-1942, 1985

MELLO, S. L. DE M. A influência de diferentes preparos de solo sobre os fatores que promovem o desenvolvimento inicial do eucalipto. Circular técnica - CHAMFLORA AGRícOLA Ltda.. 1993, 3p. (não publicado).

MILLER, H. G. Carbon x nutirent interactions - the limitations to productivity. Tree Physiology, v. 2, p. 373-385, 1986.

MISRA, R. K. Assessement of errors in nutrient analyses of roots. Australian Journal of Soil Research, v. 32, p.1275-86, 1994.

MOIR, W. H.; BACHELARD, E. P. Distribution of fine roots in tree the Pinus radiata stands near Camberra. Ecology, v. 50, p.658-662, 1969.

MULLIGAN, D. R.; SANDS, R. Dry matter, phosphorus and nitrogen partioning in three eucalyptus species grown under a nutrient deficit. New Phytologist, v. 109, n. 1, p.21-28, 1988.

NAMBIAR, E. K. S.; COTTERILL, P. P.; BOWEN, G. D. Genetic differences in root regeneration of radiata pine. Journal of Experimental Botany., v. 33, p.170-177, 1982.

NAMBIAR, E. K. S. Root development and configuration in intensively managed radiata pine plantations South Australia. Plant and Soil, v. 71 , p.37-47, 1983. 
NAMBIAR, E. K. S. Do nutrients retranslocate from fine roots? Canadian Journal Forest Research, v. 17, p.913-918, 1987.

NEAVE, I. A.; FLORENCE, R. G. Effect of configuration on the relative competitive ability of Eucalyptus maculata Hook. regrowth following clearfelling. Australian Forestry, v. 57, p.49-58, 1994.

NEGI, J. D. S.; SHARMA, D. C. Biomass estimation of two eucalyptus species by regression method. Indian Forester, v. 113, n. 3, p. 180-184, 1987.

NEWMAN, E. I. A methody of estimating the total lenght of root in a sample. Journal Of Apllied Ecology, v. 2, p.139-145,1966.

PERSSON, H. A. Spatial distribution of fine roots growth, mortality and decomposition in a young Scots pine stand in Central Sweden. Oikos, v.34, p.77-87, 1980.

PERSSON, H. A. The distribution and productivity of fine root in boreal forests. Plant and Soil, v. 71, p.87-121, 1983.

PERSSON, H.; VON FIRCKS, Y.; MAJDI, H.; NILSSON, L. O. Root distribution in a Norway spruce (Picea abies (L.) Karst) stand subjected to drought and ammonium-sulphate application. Plant and Soil, v. 168-169, p.161-165, 1995.

POWELL, S. W.; DAY Jr., F. P. Root production in four communities in the great dismal swamp. American Journal of Botany, v. 78, n. 2, p.288-297, 1991. 
RAICH, J. W.; NADELHOFFER, K. J. Belowground carbon allocation in forest ecosystems: global trends. Ecology, v. 70, p.1346-1354, 1989.

REICOSKY, D. C.; MILLINGTON, R. J.; PETERS, D. B. A comparison of three methods for estimating root lenght. Agronomy Journal, v. 62, n. 4, p.451$53,1970$.

REIS, M. G. F.; KIMMINS, J. P.; REZENDE, G. C. DE; BARROS, N. F. DE. Acúmulo de biomassa em uma sequência de idade de Eucalyptus grandis plantado no cerrado em duas áreas com diferentes produtividades. Revista Árvore, v. 9, n. 2, p.149-162, 1985.

REIS, M. G. F.; BARROS, N. F.; KIMMINS, J. P. Acúmulo de nutrientes em uma sequência de idade de Eucalyptus grandis W. Hill (ex - Maiden) plantado no cerrado em duas áreas com diferentes produtividades, em Minas Gerais. Revista Árvore, v. 11, n. 1, p.1-15, 1987.

REYNOLDS, E. R. C. Root distribution and cause of its spatial variability in Pseudotsuga taxifolia (Poir.) Britt. Plant and Soil, v. 32, p.501-517, 1970.

ROBERTS, J. A study of the root distribution and growth in a Pinus sylvestris $\mathrm{L}$. (Scots pine) plantation in East Anglian. Plant and Soil, v. 44, p.607-621, 1976.

ROBINSON, D.; BRYAN, G.; KARL, R.; WHEATLEY, R. Root-induced nitrogen mineralization. Plant and Soil, v. 117, p. 185-193, 1989.

RODE, M. D. Aboveground nutrient cycling and forest development on poor sandy soil. Plant and Soil, v. 168-169, p.337-343, 1995. 
ROWSE, H. R.; PHILLIPS, D. A. An instrument for estimating the total lenght of root in a sample. Journal of Applied Ecology, v. 11, p.309-14, 1974.

RUSSEL, R. S. Plant Root Systems - their function and interaction with the soil methods. In: Procedings Of The Symposium On The Soil/Root System. INSTITUTO AGRONÔMICO DO PARANÁ - IAPAR. Londrina, Paraná, Brazil, 1981, p. 3-20.

SÁ, J. C. de M. Manejo da feritilidade do solo no plantio direto. Castro: Fundação ABC, 1993. 96p.

SAFFORD, L. O. Effect of fertilization on biomass and nutrient content of fine roots in a beech-birch-maple stand. Plant and Soil, v. 40, p. 349-363, 1974.

SANDS, R.; GREACEN, E. L.; GERARD, C. J. Compaction of sandy soils in radiata pine forests. I. A penetrometer study. Australian Journal of Soi Research, v. 17, p. 101-113, 1979.

SANNI, R.L Jr. Vesicular-arbuscular mycorrhiza in some Nigerian soils: the effect of Gigaspora gigantea on the growth of rice. New Phytologist., v. 7, p.763-774, 1976.

SANTANTONIO, D.; HERMANN, R. K.; OVERTON, W. S. Root biomass studies in forest ecossystems. Pedobiologia, v. 17, p.1-31, 1977.

SARRUGE, J. R. \& HAAG, H. P. Análise química em plantas. Piracicaba, ESALQ, 1974. 56p. 
SINGHAL, R. M.; DEV, S. Alteration in soil carbohydrates consequent upon growing Eucalypts in Natural Sal (Shorea robusta) areas of Donn Valley. Indian Forester, v. 103, p.403-410, 1977.

SMETHURST, P. J.; NAMBIAR, E. K. S. Distribution of carbon and nutrients and fluxes of mineral nitrogen after clear-felling a Pinus radiata plantation. Canadian Journal Forest Research, v. 20, p.1490-1497, 1990.

SQUIRE, R. O.; MARKS, G. C.; CRAIG, F. C. Root development in a Pinus radiata $\mathrm{D}$. Don plantation in relation to site index, fertilizing and soil bulk density. Australian Forest Research, v. 8, p. 103-114, 1978.

STAPE, J. L. Definição do período e localização de cobertura de Eucalyptus grandis em funções da dinâmica do crescimento radicular. IPEF - Circular Técnica número 174, Piracicaba, agosto/1990.

SUTTON, R. F. Root system morphogenesis. New Zealand Journal Forest Science, v. 10, p.264-92, 1980.

TAYLOR, H. M.; UPCHURCH, D. R.; McMICHAEL, B. L. Applications and limitations of rhizotrons and minirhizotrons. Agronomy Journal. v. 75, p.1009-1015, 1990.

TENNANT, D. A test of a modified line intersect method of estimating root lenght. Journal of Ecology, v. 63, n. 3, p.995-1001, 1975.

THORNTHWAITE, C. W.; MATHER, J. R. The water balance. Publications in Climatology., v. 8, p.1-104, 1955. 
TOLLNER, E. W.; RAMSEUR, E. L.; MURPHY, C. Techniques and aproaches for documenting plant root development with $\mathrm{X}$-ray computed tomography. In: Tomography of soil-water-root processes. Special Publication, $n^{\circ} 36$, 1994.

VOGT, K. A.; EDMONDS, R. L.; GRIER, C. C. Seasonal changes in biomass and vertical distribution of mycorrhizal and fibrous-textured conifer roots in 23 and 180-year-old subalpine (Abies amabilis) stands. Canadian Journal Forest Research, v. 11, p. 223-229, 1981.

YIN, X.; JAMES, P. A. Factors affecting nitrogen concentration of fine roots in forest comunities: Regression Analysis of literature data. Forest Science, v. 37, n. 1, p.374-382, 1990.

WESTMAN, W. E.; ROGERS, R. W. Biomass and structure of a subtropical eucalypt forest, North Stradbroke Island. Australian Journal of Botany, v.25, n. 2, p.171-192, 1977. 